\title{
JUSTICIA CONSTITUCIONAL EN BOLIVIA. DESAFÍOS Y OPORTUNIDADES PARA LA TUTELA DE LOS DERECHOS DE LOS PUEBLOS INDÍGENAS EN CONFLICTOS SOCIO-AMBIENTALES
}

\author{
ARIEl PÉREZ CASTELlóN * \\ Profesor de Derecho ambiental y Derecho de hidrocarburos \\ Universidad Simón I. Patiño \\ perezcastellon@hotmail.com
}

Recibido: 12 de junio 2013 / Aceptado: 20 de diciembre 2013

\section{RESUMEN:}

Las organizaciones indígenas del país han optado regularmente en las últimas décadas por las acciones directas, de hecho, a fin de lograr el reconocimiento e implementación de sus derechos; ello, frente a una débil institucionalidad estatal en Bolivia. La Justicia Constitucional (JC) en su primera etapa de funcionamiento (1999-2011), en general no otorgó una tutela efectiva a los derechos de los pueblos indígenas vinculados a conflictos socio-ambientales. En este trabajo, se realiza un análisis sobre las dificultades y avances de la JC en dicho período. Asimismo, se exponen oportunidades y desafíos emergentes de la nueva JC Plurinacional contemplada en la Constitución de 2009, a fin de garantizar los derechos colectivos de los pueblos indígenas. Al término del documento, se plantean algunas recomendaciones para mejorar el rol de la JC en la tutela de los derechos de los pueblos indígenas, de modo congruente con las normas de la nueva Constitución.

\section{RESUM:}

En les últimes dècades, les organitzacions indígenes del país han optat freqüentment per les accions directes, de fet, per tal d'aconseguir el reconeixement i la implementació dels seus drets; això, davant d'una feble institucionalitat estatal a Bolívia. La Justícia

\footnotetext{
*** Esta investigación fue preparada para presentarse en la Conferencia Internacional de Derecho y Sociedad - 2012, organizada por Law and Society Association, en Hawaii (junio de 2012).
} 
Constitucional (JC) en la seva primera etapa de funcionament (1999-2011), en general no va atorgar una tutela efectiva als drets dels pobles indígenes vinculats a conflictes socioambientals. En aquest treball, es realitza una anàlisi sobre les dificultats i avenços de la JC en aquest període. Així mateix, s'exposen oportunitats i desafiaments emergents de la nova JC Plurinacional prevista a la Constitució de 2009, a fi de garantir els drets col·lectius dels pobles indígenes. Al final del document, es plantegen algunes recomanacions per millorar el paper de la JC en la tutela dels drets dels pobles indígenes, de manera congruent amb les normes de la nova Constitució.

\begin{abstract}
:
Recently, Bolivian indigenous organizations have regularly chosen direct actions to achieve, in fact, the recognition and the implementation of their rights; doing so, against the weak state institutions in Bolivia. In its first stage of operation (1999-2011), the Constitutional Justice (CJ) did not granted generally an effective protection of indigenous peoples' rights linked to socio-environmental conflicts. This paper analyse the difficulties and the progress of JC in that period. Likewise, emerging opportunities and the challenges of the new Plurinational JC, contained in the Constitution of 2009, are presented in order to guarantee indigenous peoples' collective rights. At the end, some recommendations are made to enhance the role of JC regarding the protection of indigenous peoples' rights, consistently with those provisions of the new Constitution.
\end{abstract}

\title{
PALABRAS CLAVE:
}

Justicia constitucional - Derechos de pueblos indígenas - Conflictos socio ambientales - Constitución boliviana de 2009 - Acción popular

\section{PARAULES CLAU:}

Justícia constitucional - Drets dels pobles indígenes - Conflictes socio-ambientals Constitució boliviana de 2009 - Acció popular

\section{KEYWORDS:}


Constitutional Justice - Rights of the indigenous peoples - Socio-environmental conflicts - 2009 Bolivian Constitution - actio popularis

Sumario: I. Introducción. II. Contexto socio-económico y político de Bolivia. 1. Modelo de desarrollo extractivista y primario exportador. 2. Histórica bonanza fiscal del Estado boliviano. 3. Debate sobre el modelo de desarrollo a implementar en el país. 4. Hegemonía del gobierno de Evo Morales y débil institucionalidad pública. III. Conflictos socio-ambientales y derechos de los pueblos indígenas en los años recientes. 1. Los conflictos socio-ambientales tienen raíz en el extractivismo. 2. Conflictos que no suceden por vacíos normativos sino por falta de implementación del derecho. 3. Por acción u omisión el Estado incumple su rol de garante de derechos. 4. Asimetría de poder y de recursos entre empresas extractivas y organizaciones indígenas. 5. Los repertorios de incidencia de las organizaciones indígenas concluyen regularmente en la acción directa. 6. Débil capacidad del gobierno para prevenir o gestionar conflictos socio-ambientales de los pueblos indígenas. 7. Los acuerdos a los que se llegan para la resolución de los conflictos, con frecuencia, no son firmes. IV. Rol desempeñado por la Justicia Constitucional para garantizar los derechos de los pueblos indígenas en conflictos socio-ambientales. 1. Naturaleza y función de la Justicia Constitucional en Bolivia. 2. Creación de la Justicia Constitucional y primer periodo de funcionamiento. 3. Resoluciones del Tribunal Constitucional relacionadas con la tutela de los derechos de los pueblos indígenas. 4. Valoración de la Justicia Constitucional en el período revisado. V. Constitución de 2009 y nuevas acciones constitucionales. 1. Principales características de la nueva Constitución Política del Estado. 2. Nuevas acciones constitucionales para la tutela de derechos. 2.1. La acción popular. 2.2. La acción de cumplimiento. VI. Conclusiones. VII. Recomendaciones.

\section{INTRODUCCIÓN}

En los 30 años de democracia en Bolivia, desde su recuperación en 1982, los pueblos indígenas del país han luchado -y luchan todavía- por la visibilización de su existencia e identidad cultural, por el reconocimiento de sus derechos económicos, sociales, culturales, territoriales y ambientales. En los años recientes han existido avances importantes en cuanto al reconocimiento constitucional de los derechos de los pueblos indígenas, en el marco de la Constitución de 2009, y muchas de las demandas actuales de los pueblos indígenas buscan que el Estado sea consecuente, en su visión de desarrollo y en la implementación de las políticas públicas del día a día, con los derechos e instituciones que ha reconocido la nueva Constitución ${ }^{1}$.

\footnotetext{
${ }^{1}$ Las organizaciones indígenas del país como la Confederación de Pueblos Indígenas de Bolivia (CIDOB), han demandado que la legislación de desarrollo de la nueva Constitución, por ejemplo, las denominadas como leyes fundamentales (v.g. Ley marco de autonomías y descentralización, Ley del régimen electoral) sean congruentes con los derechos de los pueblos indígenas contemplados en la Constitución. No obstante, organizaciones indígenas como la CIDOB han denunciado la existencia de violaciones e incongruencias constitucionales de normas como la Ley del régimen electoral, que restringe el derecho de los pueblos indígenas a elegir a los representantes indígenas ante la Asamblea Legislativa Plurinacional de acuerdo a sus normas y procedimientos propios. Cfr. IWGIA, The Indigenous World 2011 (Bolivia), pp. 173 y siguientes.
} 
Los repertorios de incidencia de los pueblos indígenas para la exigencia de sus derechos han pasado, en muchos casos, por la movilización y las acciones directas ${ }^{2}$. Ello, ante un déficit estatal e institucional que en muy raras ocasiones ha tenido la idoneidad para responder de modo oportuno y coherente a las demandas de las organizaciones indígenas. ${ }^{3}$ Un resultado de estas debilidades e inconsistencias en la gestión estatal se ha manifestado en un número creciente y cada vez más complejo de conflictos vinculados al ejercicio de los derechos de los pueblos indígenas, que en una parte significativa tienen que ver con la exigencia y respeto de los derechos territoriales de los pueblos indígenas, y dentro de ellos, con el acceso, aprovechamiento y conservación de los recursos naturales. ${ }^{4}$

En este contexto, la Justicia Constitucional, lejana a su mandato y razón de ser, con pocas excepciones ha jugado un rol pobre en la tutela de los derechos fundamentales de los pueblos indígenas. ${ }^{5}$ No obstante ello, en este trabajo partimos de la hipótesis de que la Justicia Constitucional está llamada a jugar en los próximos años un papel importante en la tutela de los derechos de los pueblos indígenas, y la resolución por vías institucionales de los conflictos entre el Estado/particulares y los pueblos indígenas. Consideramos que contribuirán a este cambio de rol de la Justicia Constitucional (JC), entre otros factores, los niveles incrementales de rendición de cuentas de la JC, así como, el escrutinio y seguimiento de una sociedad civil más informada y empoderada

\footnotetext{
${ }^{2}$ Ver una descripción de las estructuras de movilización de organizaciones como la Confederación de Pueblos Indígenas del Oriente Boliviano (CIDOB), y el Consejo Nacional de Ayllus y Markas del Qullasuyu (CONAMAQ) en GARCÍA LINERA, A., et. al., Sociología de los movimientos sociales en Bolivia. Estructuras de movilización, repertorios culturales y acción política, $4^{\mathrm{a}}$ ed., Publicación de Plural editores, AGRUCO y NCCR Norte Sur, La Paz, 2010.

${ }^{3}$ Por ejemplo, en relación a las demandas territoriales de los pueblos indígenas, que fueron objeto de varias marchas indígenas en los 90s y 2000, hasta el año 2001 apenas se había titulado como territorios indígenas el 3,8\% del total de territorios demandados en los años 90s por las organizaciones indígenas (esto es, 16 demandas territoriales interpuestas en la II Marcha por el Territorio, los Derechos de Participación Política y el Desarrollo, y 8 territorios reconocidos mediante Decretos Supremos) Cfr. BALZA ALARCÓN, R., Tierra, Territorio y Territorialidad Indígena, Santa Cruz de la Sierra, 2001, p. 20. Si bien, cabe señalar que han existido avances en la titulación de territorios indígenas en la gestión de Evo Morales en la segunda mitad del 2000. Cfr. Organización de las Naciones Unidas, Informe del Relator Especial sobre la situación de los derechos humanos y las libertades fundamentales de los indígenas, Sr. Rodolfo Stavenhagen. Misión a Bolivia, 18/02/2009.

${ }^{4}$ Ver el acápite III de este artículo en relación a los conflictos socio-ambientales y derechos de pueblos indígenas en los años recientes. Ver de modo complementario referencias a varios conflictos socioambientales en Bolivia en RIBERA ARISMENDI, M., Crónica ambiental 2007-2011. Retrospectiva y actualización de problemáticas priorizadas, Publicación de la Liga de Defensa del Medio Ambiente (LIDEMA), La Paz, 2011.

${ }^{5}$ Ver el acápite IV de esta investigación.
} 
en torno a las actuaciones de la Justicia Constitucional, y en su caso, la interpelación a la JC en relación al cumplimiento de sus mandatos institucionales.

Con este trabajo, se quiere contribuir al análisis sobre el funcionamiento de la Justicia Constitucional en una primera etapa de su trabajo (de 1999 a 2011), en relación a la tutela de los derechos indígenas, y asimismo, reflexionar sobre los desafíos y oportunidades de la Justicia Constitucional en esta materia a la luz de la nueva Constitución Política del Estado de febrero de 2009.

En este sentido, en este documento se empezará por revisar las características de los conflictos de los pueblos indígenas en los últimos años; así como, los repertorios de incidencia empleados por las organizaciones para la exigencia de sus derechos y las formas en las que se han resuelto tales conflictos. En un segundo momento del trabajo, se analizará el rol que ha jugado la Justicia Constitucional en Bolivia en cuanto a la tutela de los derechos de los pueblos indígenas en la década del 2000, señalando sus fortalezas y debilidades. En el siguiente acápite, se abordará la naturaleza y características principales de la Constitución Política del Estado promulgada en febrero de 2009, analizando de modo especial las nuevas acciones de tutela de derechos que ha introducido la nueva Constitución, centralmente la Acción Popular, y su pertinencia para la tutela de los derechos de los pueblos indígenas. En este acápite, también se realizará un breve análisis sobre las primeras acciones populares interpuestas en el país para la tutela de derechos colectivos (v.g. derechos de pueblos indígenas, derechos ambientales).

En la parte final del documento, se plantean algunas conclusiones y recomendaciones para mejorar el rol de la Justicia Constitucional en la tutela de los derechos de los pueblos indígenas.

\section{CONTEXTO SOCIO-ECONÓMICO Y POLÍTICO DE BOLIVIA}

Desde la segunda mitad de los 80 s hasta inicios del 2000, dominó en la política y economía bolivianas el modelo neoliberal, de repliegue del Estado en sus funciones sociales y económicas, y la baja participación e incidencia social en el diseño e implementación de las políticas públicas nacionales. ${ }^{6}$ Este sistema político fue

6 Cfr. CHAPLiN, A., "Movimientos sociales en Bolivia. De la fuerza al poder", en Community Development Journal, Oxford University Press, 2010. 
interpelado y debilitado con los movimientos y protestas sociales de inicios de 2000 (principalmente por las denominadas "Guerra del Agua" y "Guerra del Gas"), la renuncia del Presidente Sánchez de Lozada -como consecuencia directa de la Guerra del Gas- ${ }^{8}$, y la asunción al poder de Evo Morales (enero 2006), en cuya primera gestión presidencial se desarrolló la Asamblea Constituyente. ${ }^{9}$

La nueva Constitución Política del Estado aprobada mediante referendo popular en enero de 2009, si bien con incoherencias y contradicciones, plasma una visión del Estado y de la sociedad en la que se jerarquiza el interés colectivo, el rol del Estado en la administración de los bienes públicos nacionales, y la construcción de un Estado plurinacional con autonomías políticas ${ }^{10}$. La nueva Constitución también contempla el reconocimiento de un catálogo amplio de derechos y garantías constitucionales, entre ellos, todo un capítulo consagrado a los derechos de los pueblos indígenas ${ }^{11}$. Bolivia transita en la actualidad por el duro y desafiante camino del desarrollo e implementación de los derechos reconocidos por la CPE, camino en el que ya se visibilizan dificultades e incoherencias, y que en este sentido requiere de un gran esfuerzo de los actores sociales, políticos, y económicos del país para garantizar la integridad y respeto del texto constitucional ${ }^{12}$. Las organizaciones indígenas constatan con demasiada frecuencia que el reconocimiento constitucional de sus derechos es apenas un nuevo punto de partida en los procesos de exigencia e implementación de los mismos.

\footnotetext{
${ }^{7}$ Ver información complementaria sobre estas movilizaciones sociales en CRABTREE, J., Perfiles de la protesta. Política y movimientos sociales en Bolivia, La Paz, Fundación UNIR y Fundación PIEB, 2005.

${ }^{8}$ El ex Presidente Gonzalo Sánchez de Lozada fue uno de los principales abanderados de las políticas de privatización en el país, desde mediados de los 80s hasta inicios de 2000.

${ }^{9}$ La Asamblea Constituyente fue una demanda histórica de varias organizaciones sociales del país, como la CIDOB. La realización de la Asamblea Constituyente fue demandada por organizaciones indígenas en la III Marcha Indígena (2000) y en la IV Marcha Indígena (2002). Cfr. GARCÍA LINERA, A., et. al., op. cit., p. 258.

${ }^{10}$ Un análisis detallado de elementos centrales de la nueva Constitución puede revisarse en ALBÓ, X., et. al., Miradas. Nuevo texto constitucional, Publicación de Idea Internacional, Universidad Mayor de San Andrés y Vicepresidencia del Estado Plurinacional, La Paz, 2010.

${ }^{11}$ Cfr. Artículo 30 y siguientes de la Constitución Política del Estado.

${ }^{12}$ Por ejemplo, en opinión de organizaciones indígenas originarias como CONAMAQ ha existido un recorte de los derechos contemplados en la CPE con la Ley de deslinde Jurisdiccional (Ley $\mathrm{N}^{\mathrm{o}} 73$ ), que establece el marco para la aplicación de la Jurisdicción Indígena Originaria Campesina y su relación con las otras jurisdicciones contempladas por la Constitución. En este sentido, CONAMAQ ha demandado la modificación de la Ley de deslinde jurisdiccional a fin de garantizar su congruencia con la Constitución. Ver sobre el particular: http:/www.eldiario.net/noticias/2013/2013_09/nt130919/politica.php?n=74\&conamaq-pide-modificaciones-a-ley-de-deslinde-jurisdiccional.
} 
A continuación, de modo sintético se describen algunas de las principales características del contexto socio-económico y político del país:

\section{Modelo de desarrollo extractivista y primario exportador}

La base económica del país mantiene e incrementa su dependencia en la explotación de recursos naturales, centralmente de hidrocarburos y minerales. Más del 75\% de las exportaciones bolivianas corresponden a dichos recursos no renovables ${ }^{13}$. Si bien, con el Referéndum de la Política Energética de 2004 y la Ley de Hidrocarburos 3058 de 2005 se mejoró notablemente la participación del Estado en la renta de los hidrocarburos ${ }^{14}$, el gasto de esta renta, en general, no se ha orientado para promover un modelo de desarrollo de base ancha y productivo ${ }^{15}$, que permita una mejora sostenida en la inclusión social y económica de una mayoría de los/as bolivianos/as. Las políticas de otorgamiento de diferentes tipos de bonos a población carenciada del país, así como, otras políticas sociales, han ayudado a disminuir los niveles de pobreza ${ }^{16}$; no obstante, Bolivia sigue siendo uno de los países con mayores niveles de inequidad en el mundo ${ }^{17}$.

\section{Histórica bonanza fiscal del Estado boliviano}

Los altos precios de las materias primas en el mercado internacional en los últimos años, el incremento en los volúmenes de producción de gas natural, y el aumento significativo del government take en el caso de los hidrocarburos, han multiplicado las rentas estatales por concepto de estas materias primas. Así, en relación a los hidrocarburos, la renta estatal ha subido de 1.009 millones de dólares en 2005 a 2.299 millones de dólares en $2009^{18}$.

\footnotetext{
13 En enero de 2012, el $75.9 \%$ de las exportaciones bolivianas correspondían a la extracción de hidrocarburos y minerales. Cfr. Instituto Nacional de Estadística, Resumen estadístico - Enero 2012.

${ }^{14}$ Se paso del 18\% al 50\% de participación estatal en la renta sobre la producción de hidrocarburos.

${ }^{15}$ Cfr. CEDLA, Las prefecturas no usan la renta de los hidrocarburos para el desarrollo. Ingresos millonarios, gastos improductivos y poca transparencia, 2010. Ver el documento en línea en: http://ns.plataformaenergetica.org/sites/default/files/separata\%20CEDLA\%20abr_2010.pdf.

${ }^{16}$ Conforme a la CEPAL, desde 2007 a 2011, los índices de pobreza bajaron en el país del 61 al 49\%. Cfr. http://www.bolpress.com/art.php?Cod=2011120702.

${ }^{17}$ En 2011, Bolivia ocupaba el último lugar en América Latina en la medición de la desigualdad en la distribución del ingreso (índice Gini). Cfr. http://www.pieb.com.bo/sipieb_notas.php?idn=5677.
}

${ }^{18}$ CEDLA, op. cit., p. 2 
A contrapelo de esta bonanza fiscal, las instancias estatales en los diferentes niveles de gobierno adolecen de una baja capacidad de gasto y gestión ${ }^{19}$. De otra parte, este aumento exponencial de la renta ha incrementado también la puja y conflictos entre diversas unidades territoriales y sectores sociales para participar o ampliar su participación en la torta de la renta de las industrias extractivas.

\section{Debate sobre el modelo de desarrollo a implementar en el país}

La Constitución Política del Estado revela el debate no acabado sobre el modelo de desarrollo que se debería implementar en el país, contemplando normas como la que establece la utilidad pública de las actividades de exploración, explotación y otras vinculadas al aprovechamiento de los recursos naturales no renovables ${ }^{20}$, al mismo tiempo que reconoce el derecho-deber al ambiente saludable y equilibrado de las generaciones presentes y futuras, o el estatus de especial protección de la cuenca amazónica. $^{21}$

Esta contraposición de visiones se traslada también al ámbito de las políticas públicas, la aprobación de proyectos de infraestructura, entre otros. Una de las iniciativas públicas que patentiza de mejor forma este debate medular de visiones de desarrollo, es el de la construcción de la carretera Villa Tunari - San Ignacio de Moxos, cuyo diseño proyectado atraviesa el núcleo del Territorio Indígena y Parque Nacional Isiboro Sécure (TIPNIS). La construcción de esta infraestructura vial se inició por parte del gobierno vulnerando normas constitucionales y tratados internacionales ratificados por el país, como los vinculados con el derecho de consulta previa de los pueblos indígenas. ${ }^{22}$ Organizaciones indígenas de tierras bajas y de tierras altas del país, han manifestado su

\footnotetext{
${ }^{19}$ Así por ejemplo, hasta noviembre de 2009, unos 2.684 millones de bolivianos se habían acumulado como saldo no ejecutado de las Gobernaciones Departamentales. Cfr. CEDLA, ibíd., p. 7.

${ }^{20}$ Cfr. Artículo 356 de la Constitución Política del Estado (CPE).

${ }^{21}$ Cfr. Artículos 33 y 390 de la CPE.

${ }^{22}$ En relación al incumplimiento del Estado boliviano sobre su deber de consultar a los pueblos indígenas de modo previo a la realización de varias medidas administrativas y legislativas vinculadas a la construcción de la carretera Villa Tunari-San Ignacio de Moxos ver el informe de la Defensoría del Pueblo que identifica responsabilidades estatales sobre el particular Cfr. Defensoría del Pueblo, Informe Defensorial respecto a la violación de los derechos humanos en la Marcha Indígena, La Paz, noviembre de 2011, pp. 100 y siguientes.
} 
oposición a que esta construcción atraviese el núcleo del territorio indígena y área protegida, a través de largas marchas y otras acciones directas. ${ }^{23}$

El conflicto del TIPNIS es emblemático de la colisión de visiones de desarrollo en Bolivia. De una parte, la voluntad desarrollista y expansionista del gobierno boliviano sobre la frontera amazónica, sobre áreas protegidas y territorios indígenas, con la ampliación de la frontera agrícola, y el desarrollo de proyectos extractivos y de infraestructura (v.g. carreteras, plantas hidroeléctricas) ${ }^{24}$, que obedecen a lógicas de mercado regionales como la Iniciativa para la Integración de la Infraestructura Regional Sudamericana (IIRSA), pero sobre todo a la presión y voracidad de recursos naturales y energéticos por parte de Brasil en la cuenca andino-amazónica- ${ }^{25}$. Y de otra parte, una visión liderada por pueblos indígenas de tierras bajas y altas que plantean la necesidad de un modelo de desarrollo armónico con el respeto a la Madre Tierra, y con los derechos fundamentales de los pueblos indígenas ${ }^{26}$.

\section{Hegemonía del gobierno de Evo Morales y débil institucionalidad pública}

El Presidente Evo Morales desde su primera victoria electoral con 53,7\% de votos en diciembre de 2005 , y su reelección con $64,2 \%$ de votos en 2009 , cuenta con un poder hegemónico en el país ${ }^{27}$, controlando diferentes órganos del Poder estatal (entre ellos, la Asamblea Legislativa Plurinacional, y partiendo de un proceso de selección cuestionado de Magistrados/as del Órgano Judicial en $2011^{28}$, se cree que puede tener ascendente

\footnotetext{
${ }^{23}$ La más importante acción colectiva desarrollada por las organizaciones indígenas para impedir que la carretera atraviese el Territorio Indígena y Parque Nacional Isiboro Sécure, la constituyó la VIII Marcha indígena realizada en 2011. Ver GUZMÁN, I., Octava marcha indígena en Bolivia: Por la defensa del territorio, la vida y los derechos de los pueblos indígenas, Publicación del Centro de Investigación y Promoción del Campesinado (CIPCA), La Paz, 2012.

${ }^{24}$ Una descripción general de diferentes políticas y proyectos extractivos en las gestiones de gobierno de Morales puede revisarse en RIBERA ARISMENDI, M. O., Crónica ambiental 2007-2011. Retrospectiva $y$ actualización de problemáticas priorizadas, Publicación de la Liga de Defensa del Medio Ambiente (LIDEMA), La Paz, 2011.

${ }^{25}$ Cfr. PÉREZ CASTELLÓN, A., "Política energética y “vivir bien”: algunas herramientas conceptuales y de gestión para tender cables a tierra", en Revista Artículo Primero - CEJIS, La Paz, enero 2011.

${ }^{26}$ En el caso de la plataforma de demandas de la VIII Marcha Indígena, éstas estaban dirigidas al vivir bien en los términos del respeto a la tierra, al medio ambiente, a las formas de vida propia, a sus visiones de desarrollo y a la dignidad de las familias que lo habitan. Cfr. GUZMÁN, I., op. cit., p. 22.

${ }^{27}$ Cfr. ZUAZO, M., “LLos movimientos sociales en el poder? El gobierno del MAS en Bolivia”, en Revista Nueva Sociedad, № 227, mayo-junio 2010.

${ }^{28}$ La Alta Comisionada de las Naciones Unidas para los Derechos Humanos en su informe anual sobre las actividades de su oficina en el Estado Plurinacional de Bolivia (febrero 2012), destaca que el resultado de
} 
sobre Magistrados/as electos del Órgano Judicial ${ }^{29}$ ), e instancias de gobierno subnacionales. Una concentración tan grande de poder, y la aspiración de mantenerse en el mismo por los siguientes años (Evo Morales ha expresado que se presentará a una nueva elección presidencial en 2014), está debilitando la construcción de institucionalidad democrática en Bolivia. El equilibrio y control entre los órganos de poder se encuentra muy limitado, y sin éste, el estado de derecho e imperio de la ley tienden a enervarse.

El gobierno con frecuencia asume un talante vertical a la hora de construir e implementar políticas públicas ${ }^{30}$, y por otra parte, asume una visión maniquea de los actores sociales que tienen "legitimidad partidaria-social" para participar en dichos procesos, y quienes no la poseen, por tener una posición crítica al gobierno ${ }^{31}$. Ello limita o impide el consenso y la articulación de actores en el diseño de políticas, y por ende, el nivel de apropiación e implementación de las mismas. Como correlato a este espíritu vertical y "endogámico" de hacer política, se observa en los últimos años un número

este novedoso proceso electoral proyecta una composición intercultural con equidad de género en los altos tribunales de justicia. No obstante, también advierte las dificultades que hubo en el proceso: se registró un notable porcentaje de votos nulos y blancos, así como críticas por parte de la oposición del proceso en su conjunto (....) El procedimiento de evaluación de méritos de los postulantes se desarrolló de manera transparente, aunque podrían haberse incluido criterios meritocráticos con ponderaciones para un procedimiento de evaluación más completo. Otro aspecto a mejorar es el proceso de información al público sobre las candidaturas. Ambos procesos ameritan ser revisados en el futuro. Cfr. Organización de las Naciones Unidas; Informe de la Alta Comisionada de las Naciones Unidas para los Derechos Humanos sobre las actividades de su oficina en el Estado Plurinacional de Bolivia. Consejo de Derechos Humanos. $19^{\circ}$ Período de Sesiones, 2/02/2012.

${ }^{29}$ En el Informe de la Defensoría del Pueblo a la Asamblea Legislativa Plurinacional (2012), esta institución alerta sobre la crisis del sistema de justicia en el país, uno de cuyos componentes reside en su aparente permeabilidad a la influencia del poder político. En similar sentido, la Defensoría del Pueblo citando un informe de la Comisión Interamericana de Derechos Humanos de la OEA, señala que la actividad jurisdiccional en Bolivia se encuentra caracterizada, entre otros elementos, por: una permanente amenaza de debilitamiento de la independencia judicial, debido a la presión e injerencia de otros órganos o poderes públicos y de una reciente tendencia de judicialización de la política. Cfr. Defensoría del Pueblo, XV Informe a la Asamblea Legislativa Plurinacional 2012, La Paz, 2013.

${ }^{30}$ Por ejemplo, en junio de 2011, el Presidente Evo Morales al referirse a la construcción de la carretera a través del TIPNIS señalaba que esta se realizaría de modo irremisible: "Tenemos recursos económicos garantizados y aparecen algunos supuestos defensores del medio ambiente que usan a nuestros hermanos para que no se realice este camino. Quieran o no quieran vamos a construir y en nuestra gestión vamos a entregar el camino Villa Tunari-San Ignacio de Moxos". Cfr. http://www.lostiempos.com/ diario/actualidad/economia/20110630/evo-\%E2\%80\%9Cquieran-o-no\%E2\%80\%9D-se-construira-lacarretera-a_131848_267094.html.

${ }^{31}$ En relación a la participación social en el diseño de políticas públicas, Moira Zuazo expresa: (...) desde la perspectiva del Estado, lo que tenemos hoy es una participación organizada, dosificada, en la que el gobierno define la agenda. Desde la perspectiva de la sociedad, las organizaciones sociales son convocadas a iniciativa estatal y, cuando participan, lo hacen de forma fragmentada. Cfr. ZUAZO, M., op. cit., p. 134. 
ascendente de $\operatorname{conflictos}^{32}$, entre los que destacan aquellos relacionados con la conculcación de los derechos de los pueblos indígenas y el desarrollo de proyectos de exploración/explotación de recursos naturales en sus territorios.

\section{CONFLICTOS SOCIO-AMBIENTALES Y DERECHOS DE LOS PUEBLOS INDÍGENAS EN LOS AÑOS RECIENTES}

En la lógica de este trabajo, es pertinente realizar el análisis de las características principales de los conflictos socio-ambientales relacionados con el ejercicio de derechos de los pueblos indígenas en Bolivia en los años recientes, cuáles han sido los repertorios de incidencia aplicados por las organizaciones para la tutela de sus derechos, y cuáles las vías de resolución de los conflictos. Con estos antecedentes, en el acápite cuatro se revisará y analizará el rol que ha jugado la Justicia Constitucional en la tutela de los derechos indígenas relacionados con conflictos socio-ambientales.

Se analizarán de modo escueto las características de los conflictos socio-ambientales a la luz de tres casos emblemáticos, a saber: el caso del Jach'a Suyu Pakajaki y la Corporación Minera de Bolivia (COMIBOL), en relación al funcionamiento de la Planta Hidrometalúrgica de Coro-Coro (ubicada en el Departamento de La Paz); el caso de la construcción de la carretera Villa Tunari - San Ignacio de Moxos que el gobierno nacional pretende que atraviese el Territorio Indígena y Parque Nacional Isiboro Sécure; y el caso de la Asamblea del Pueblo Guaraní de Itika Guasu y la empresa Repsol, en relación a la exploración y explotación de hidrocarburos en el campo Margarita ${ }^{33}$.

\footnotetext{
${ }^{32}$ Cfr. Informe sobre conflictividad en Bolivia (Junio a diciembre de 2010), Fundación UNIR, La Paz, febrero de 2011. Los conflictos en el período de estudio se incrementaron respecto al mismo período en 2009, en más del 300\%. Ver en: http:/www.unirbolivia.org/nueva3/index.php?option=com_content $\&$ view $=$ category \&layout=blog $\& \mathrm{id}=85 \&$ Itemid $=59$.

${ }^{33}$ No es objetivo de este trabajo describir y analizar en detalle dichos conflictos, sino específicamente, relevar algunas de sus características más salientes y comunes en el marco de este acápite. Para profundizar información sobre estos casos se sugiere revisar VARGAS, M., "Demanda de Consulta previa en territorio Jach'a Suyu Pakajaqi”, en Revista Artículo Primero: Industrias Extractivas. Políticas y Derechos, Año 14, No 21, Publicación de CEJIS, Santa Cruz, 2011; CIDOB, Bolivia Plurinacional, VIII Marcha indígena: La defensa del TIPNIS unió a toda Bolivia, Santa Cruz, Año 3, No 4, 2012; Programa de Industrias Extractivas de Oxfam en Bolivia, Repsol YPF en el Chaco boliviano: El pueblo guarani en el proceso de defensa de sus derechos, 2007.
} 


\section{Los conflictos socio-ambientales tienen raíz en el extractivismo}

Como se ha dicho antes, la economía boliviana tiene una base eminentemente extractivista. Al mismo tiempo, se debe señalar que una buena parte de las áreas de exploración y explotación de hidrocarburos y minerales, y de desarrollo de grandes infraestructuras (v.g. vial, energética) se traslapan con territorios de pueblos indígenas y originarios de tierras bajas y altas. ${ }^{34}$ En general, ya se traten de empresas estatales nacionales, como COMIBOL o Yacimientos Petrolíferos Fiscales Bolivianos (YPFB), o de empresas privadas transnacionales (como Repsol o Total), sus operaciones extractivas con frecuencia han incumplido normas sociales y/o ambientales del país ${ }^{35}$. Los altos precios de las materias primas vigentes en el mercado internacional en los últimos años, han alentado la profundización del modelo extractivista en Bolivia, en general, externalizando sus impactos sociales y ambientales. La hermana siamesa del extractivismo es el rentismo, que desde hace muchos años "legitima" el statu quo extractivista, y adormece la iniciativa social/estatal para generar o respetar otros modelos posibles de desarrollo.

Desafortunadamente, en los siguientes años se prevé la ampliación de la frontera extractivista hacia la amazonía boliviana ${ }^{36}$, la región más biodiversa y el territorio ancestral de muchos pueblos indígenas del país. De ello se puede inferir, que de no producirse cambios o ajustes en la visión estatal extractivista, es previsible anticipar un incremento y profundización de los conflictos socio-ambientales con afectación de los derechos de los pueblos indígenas.

34 Cfr. PAYE, L., et al., Compendio de espaciomapas de TCO en tierras bajas. Tenencia y aprovechamiento de recursos naturales en territorios indígenas, Publicación de CEDLA, La Paz, 2011.

${ }^{35}$ Algunos ejemplos de estos incumplimientos se pueden ver en la siguiente bibliografía Revista Artículo Primero: Industrias Extractivas. Politicas y Derechos, Año 14, No 21, Santa Cruz, 2011 (Caso COMIBOL-Jach'a Suyu Pakajaqi); Programa de Industrias Extractivas de Oxfam en Bolivia, Repsol YPF en el Chaco boliviano: El pueblo guaraní en el proceso de defensa de sus derechos, 2007 (Caso APG Itika Guasu-Repsol) http://www.intermonoxfam.org/es/documentos/05/08/07/repsol-ypf-en-chacoboliviano-pueblo-guarani-en-proceso-de-defensa-de-sus-derech; CEADESC, Total E\&P Bolivie y sus impactos en los derechos humanos del pueblo guarani de la capitanía de Muyupampa, 2011 (Caso Asamblea del Pueblo Guaraní - Total E\&P Bolivie) http://www.ceadesc.org/2012/01/total-ep-bolivie-ysus-impactos-en-los-derechos-humanos-del-pueblo-guarani-de-la-capitania-de-muyupampa/. Cabe destacar en el caso de Repsol, la aprobación de una Política empresarial de Relacionamiento con Comunidades Indígenas en 2007, cuyos lineamientos se espera puedan mejorar la prevención y reparación de daños sociales y ambientales en las operaciones de la empresa en el futuro.

${ }^{36}$ A título de ejemplo, cabe señalar que el Decreto Supremo No 29130 de mayo de 2007 reserva 21 áreas de interés hidrocarburífero a favor de YPFB para la exploración y explotación de hidrocarburos, mientras que el Decreto Supremo No 676 (octubre 2010) amplía las áreas de interés hidrocarburífero reservadas a favor de YPFB a un número de 56, varias de las cuales se encuentran en la ecorregión amazónica, y traslapadas con áreas protegidas y territorios indígenas. Cfr. PAYE, L., et al., op. cit. 


\section{Conflictos que no suceden por vacíos normativos sino por falta de implementación del derecho}

Si bien la legislación boliviana está en pleno proceso de revisión y formulación para ajustarse a los mandatos de la nueva Constitución, al mismo tiempo se puede afirmar que tiene una sólida y amplia base en los derechos y garantías de las personas, reconocidos por la Constitución de 2009. De modo adicional, se debe enfatizar que conforme al propio texto constitucional los tratados y convenios internacionales en materia de derechos humanos ratificados por la Asamblea Legislativa Plurinacional, forman parte del bloque de Constitucionalidad. ${ }^{37} \mathrm{Y}$ aún más, cuando los derechos contemplados en los tratados de derechos humanos firmados o ratificados por el país fuesen más favorables a las personas que los derechos contenidos en la Constitución, aquéllos tendrán aplicación preferente, por tanto, naturaleza supra-constitucional. ${ }^{38}$ Asimismo, los derechos constitucionales deben ser interpretados a la luz de los tratados internacionales de derechos humanos, cuando éstos contemplen normas más favorables. ${ }^{39}$ La voluntad del Constituyente en este sentido es nítida, dotar el máximo resguardo estatal a los derechos humanos de sus habitantes. Ello, frente a un pasado no muy lejano de delitos de lesa humanidad cometidos en regímenes dictatoriales en el país, muchos de ellos todavía pendientes de esclarecimiento y sanción.

Cabe señalar, que en el ámbito de los derechos de los pueblos indígenas, Bolivia ratificó el Convenio 169 de la OIT, sobre Pueblos Indígenas y Tribales en países independientes, en julio de 1991; en tanto que, fue el primer país en ratificar la Declaración de las Naciones Unidas sobre los Derechos de los Pueblos Indígenas en noviembre de 2007. En consecuencia, estos dos instrumentos internacionales forman parte del bloque de Constitucionalidad, y sus normas pueden llegar a tener carácter supra-constitucional en caso de contemplar derechos más favorables a los pueblos indígenas que los del texto constitucional.

A contrapelo de estos preceptos constitucionales, como veremos a continuación, varias políticas y prácticas de diferentes actores estatales están vulnerando de modo reiterado derechos de pueblos indígenas, entre ellos, el derecho a la consulta previa, libre e informada. Así, en relación a las operaciones del Complejo Hidrometalúrgico de

\footnotetext{
${ }^{37}$ Cfr. Artículo 13, IV; y Artículo 410, II de la Constitución Política del Estado.

${ }^{38}$ Cfr. Artículo 256, I Constitución Política del Estado.

${ }^{39}$ Cfr. Artículo 256, II Constitución Política del Estado
} 
Corocoro y la demanda de consulta previa del Jach'a Suyu Pakajaqi, en septiembre de 2010, una alta autoridad del Ministerio de Minería y Metalurgia señalaba que dicho Ministerio no podía realizar el proceso de consulta previa debido a la falta de una norma reglamentaria sobre consulta para el sector minero ${ }^{40}$, criterio estatal que viola la cláusula de operatividad propia de los derechos constitucionales que reconoce la Constitución boliviana $^{41}$. Por otra parte, en el caso de la carretera Villa Tunari-San Ignacio de Moxos, no se cumplió con el procedimiento de consulta previa (prelegislativa) a las organizaciones indígenas de modo previo a la promulgación de la ley que aprobó el préstamo del Banco Nacional de Desarrollo Económico y Social (BNDES) para la construcción de la carretera, ni de modo previo al inicio de la construcción de dicha infraestructura ${ }^{42}$. De hecho, ya iniciada la construcción de la carretera y ante las denuncias de las organizaciones indígenas sobre el incumplimiento de la Constitución y los tratados internacionales en relación al derecho a la consulta previa, el Vicepresidente del Estado boliviano señalaba que la consulta previa no era aplicable al caso del TIPNIS debido a que se trataba de un proyecto de infraestructura y no de explotación de recursos naturales ${ }^{43}$.

\section{Por acción u omisión el Estado incumple su rol de garante de derechos}

Con frecuencia, las instituciones estatales son débiles y deficientes para cumplir con sus mandatos de control, fiscalización y, en su caso, sanción, ante el incumplimiento de normas sociales o ambientales por parte de las empresas extractivas en los territorios indígenas $^{44}$. Pero también cabe señalar que falta en muchos funcionarios públicos mayor información y sobre todo sensibilización sobre los contenidos, alcances e importancia de los derechos indígenas. Han sido especialmente dañosos en términos de discurso y de concepción sobre los derechos indígenas los pronunciamientos públicos del Presidente del Estado, del Vicepresidente y del Presidente de YPFB, en sentido de

\footnotetext{
${ }^{40}$ Este criterio fue expresado por una autoridad nacional del sector minero en una conversación informal con el autor.

${ }^{41}$ Cfr. Artículo 109, I de la Constitución Política del Estado: "Todos los derechos reconocidos en la Constitución son directamente aplicables...".

${ }^{42}$ Cfr. Defensoría del Pueblo, Informe Defensorial respecto a la violación de los derechos humanos en la Marcha Indígena, La Paz, noviembre de 2011, pp. 100 y siguientes.

${ }^{43}$ Cfr. http://www.paginasiete.bo/2012-03-09/Nacional/Destacados/37Aldia02-090312.aspx

${ }^{44}$ Cfr. RIBERA ARISMENDI, M. O., op. cit. y GRUENBERGER, J.; ZAMBRANA, G., "Política ambiental", en Informe del estado ambiental de Bolivia 2010, Publicación de LIDEMA, La Paz, 2010.
} 
que la consulta previa representa un obstáculo para las inversiones, y que algunos pueblos guaraníes usan la consulta para chantajear a las empresas petroleras, entre otras afirmaciones. $^{45}$

Por otra parte, existen casos en los que los representantes estatales se apartan de su mandato de garante de derechos de los pueblos indígenas en el relacionamiento de estos con empresas extractivas, bajo el argumento de que se trata de "relaciones entre privados". Ello sucedió, por ejemplo, en el largo proceso de negociación del Acuerdo de colaboración de Repsol YPF al Plan de Desarrollo Indígena de la Asamblea del Pueblo Guaraní de Itika Guasu (APG IG). En varias oportunidades, la APG IG demandó la participación e intermediación de las autoridades estatales para llegar a un acuerdo con Repsol que sea congruente con las normas nacionales e internacionales de derechos humanos. Aunque hubo reuniones del poder ejecutivo con la organización indígena, éstas no fueron efectivas, y en definitiva el Ministro de Hidrocarburos manifestó a la APG Itika Guasu que la negociación entre la organización indígena y la empresa petrolera se trataba de un asunto entre privados, por lo que dispensaba su participación en ella. ${ }^{46}$

Luego de seis años de negociación, de borradores de convenios con cláusulas leoninas elaboradas por Repsol ${ }^{47}$, de acciones de presión de la organización indígena sobre Repsol para que esta cumpla con sus obligaciones legales, etc., en diciembre de 2010, finalmente se firmó el Acuerdo de cooperación entre la APG IG y Repsol YPF, que conforme a la organización indígena comprende cláusulas muy ventajosas para el pueblo guaraní ${ }^{48}$. Lo preocupante del caso es que YPFB, quien suscribe los contratos de operación en nombre del Estado boliviano con empresas petroleras como Repsol, desconoce el texto de este Acuerdo, según ha afirmado un miembro del Directorio de la empresa estatal ${ }^{49}$. Con ello, el Estado ha fallado en su deber constitucional de

\footnotetext{
45 Cfr. http://www.la-razon.com/economia/Morales-dice-guaranies-chantajean_0_1546645340.html http://www.lostiempos.com/diario/actualidad/nacional/20100117/indigenas-alistan-movilizacion-por-ladefensade-su_54082_95810.html

${ }^{46}$ Cfr. Comunicado de la Asamblea del Pueblo Guarani Itika Guasu y Equipo Nizkor (enero de 2012). http://www.rebelion.org/noticia.php?id=142360

${ }^{47}$ Ver acápite 4 del presente apartado.

${ }^{48}$ Entre ellas, auditorías ambientales quinquenales, y un Fondo de Inversión para la APG IG sufragado por Repsol y las otras empresas contratistas.

49 Cfr. Declaración a la prensa de Luis Lafuente, integrante del Directorio de YPFB. http://www.hidrocarburosbolivia.com/bolivia-mainmenu-117/ypfb-petroleras-mainmenu-118/48089ypfb-desconoce-existencia-de-fondo-extraterritorial-financiado-por-repsol-a-favor-de-la-apg-itika-
} 
protección de los derechos de los pueblos indígenas, así como, en su deber de preservar y gestionar de modo adecuado el patrimonio y bienes estatales.

De modo adicional a estas omisiones de obligaciones de hacer del Estado boliviano, cabe señalar que el Estado mismo, a través de algunas de sus empresas estatales, ha vulnerado derechos de los pueblos indígenas ${ }^{50}$. Un caso emblemático de estas vulneraciones es el de la empresa COMIBOL que gestiona el Complejo Hidrometalúrgico de Corocoro. Dicho complejo para el procesamiento de cobre fue inaugurado por el Presidente del Estado e inició sus operaciones sin contar con una licencia ambiental ${ }^{51}$, y sin haberse realizado un proceso de consulta previa a la organización indígena originaria Jach’a Suyu Pakajaqi, conforme a lo mandado por la Constitución e instrumentos internacionales como el Convenio 169 de la OIT.

\section{Asimetría de poder y de recursos entre empresas extractivas y organizaciones indígenas}

Un hecho característico de los conflictos socio-ambientales entre organizaciones indígenas y empresas extractivas tiene que ver con la brecha de poder, recursos e información que existe entre unos y otros, y que lamentablemente ha marcado en muchos casos, una línea de acción vertical y dominante de las empresas extractivas sobre las organizaciones indígenas. ${ }^{52}$ Esta condición es agravada, como se ha dicho en el anterior acápite, cuando el Estado se sustrae de sus obligaciones de garante de derechos de los pueblos indígenas. A título de ejemplo, cabe señalar que en el caso APG IG - Repsol YPF, la empresa petrolera hacia el año de 2007 presentó a consideración de la APG IG un borrador de convenio de colaboración que incluía una cláusula por la que la organización indígena se obligaba a renunciar a su derecho de plantear acciones contra Repsol, por hechos pasados y futuros por los próximos 20 años a partir de la

guasu.html En este sentido, YPFB desconocería, por ejemplo, si la empresa estatal deberá asumir los costos del Fondo de Inversión para la APG IG como costos recuperables, reembolsables a Repsol.

50 Cfr. Revista Artículo Primero: Industrias Extractivas. Políticas y Derechos, Año 14, No 21, Publicación de CEJIS, Santa Cruz, 2011.

${ }^{51}$ Cfr. http://www.jornadanet.com/n.php?a=39755-1

${ }^{52}$ Cfr. Revista Artículo Primero: Industrias Extractivas. Políticas y Derechos; y Programa de Industrias Extractivas de Oxfam en Bolivia, Repsol YPF en el Chaco boliviano: El pueblo guarani en el proceso de defensa de sus derechos, 2007. 
firma del convenio ${ }^{53}$. Cláusula que fue censurada y denunciada por la organización indígena. No obstante ello, debido a la complejidad técnica de los convenios o documentos en el sector extractivo, y en ausencia de apoyo estatal o de otras organizaciones de la sociedad civil, cláusulas como la referida, bien pueden pasar inadvertidas para muchas organizaciones indígenas, vulnerando sus derechos $\mathrm{y}$ autonomía.

Con todo, se debe manifestar que a diferencia de la situación en décadas pasadas el nivel de empoderamiento de las organizaciones indígenas en relación al conocimiento y ejercicio de sus derechos es mucho mayor en el presente. A lo que han contribuido iniciativas de apoyo y acompañamiento de organizaciones de la sociedad civil, y en las que es de esperar un mayor involucramiento del Estado boliviano.

\section{Los repertorios de incidencia de las organizaciones indígenas concluyen regularmente en la acción directa}

Dada la debilidad y poca confianza en la institucionalidad estatal y el estado de derecho por parte de las organizaciones indígenas y de la población boliviana en general ${ }^{54}$, se ha generado entre éstos una especie de "sentido común", respecto a que lo único que funciona para que los órganos estatales atiendan a sus demandas son las acciones directas de hecho. Las organizaciones indígenas en muchos casos inician sus acciones de incidencia con cartas, solicitudes de reuniones o audiencias con las autoridades públicas para hacer conocer sus demandas, escalando a denuncias por incumplimientos estatales, y terminando en acciones directas como: huelgas, bloqueos de caminos o de instalaciones estratégicas, marchas, etc. ${ }^{55}$

En varios casos, las acciones directas de las organizaciones son reprimidas con violencia por el aparato estatal, profundizando con ello la brecha de desconfianza entre unos y otros actores. Por ejemplo, en el caso del conflicto por la carretera del TIPNIS,

\footnotetext{
53 Cfr. http://www.eleconomista.es/mercados-cotizaciones/noticias/290357/10/07/RSC-Repsol-YPFpresiona-a-los-indigenas-de-Bolivia-para-que-renuncien-a-sus-derechos-segun-Intermon-Oxfam.html

${ }^{54}$ Por ejemplo, de acuerdo a los resultados del Latinobarómetro en 2010, el 65\% de la población boliviana señalaba que tenía poca o ninguna confianza en la administración pública. Mientras que el $81 \%$ consideraba que los ciudadanos nacionales cumplen poco o nada con la ley. Cfr. http://www.latinobarometro.org/latOnline.jsp

55 Cfr. GARCÍA LINERA, A., et. al., op. cit., y Revista Artículo Primero: Industrias Extractivas. Políticas y Derechos, Año 14, No 21, Publicación de CEJIS.
} 
pueblos indígenas de tierras bajas y altas del país tuvieron que realizar una marcha -la VIII Marcha Indígena- de más de $900 \mathrm{~km}$, durante 66 días, para que el gobierno asuma su obligación estatal de preservar el Parque Nacional y Territorio Indígena Isiboro Sécure, y en consecuencia disponga el mandato legal de que ninguna carretera pueda atravesar el TIPNIS. ${ }^{56}$ Asimismo, cabe mencionar que durante la VIII Marcha se produjo una dura represión policial a los/as indígenas marchistas ${ }^{57}$, que a la fecha de redacción de este artículo no ha sido sancionada por la justicia boliviana.

Como se verá en acápites siguientes ${ }^{58}$, las organizaciones indígenas en general no han empleado las acciones judiciales como parte de sus repertorios de incidencia para la tutela de sus derechos vinculados a conflictos socio-ambientales, en muchos casos, debido a su poca información y desconfianza en el sistema judicial boliviano.

\section{Débil capacidad del gobierno para prevenir o gestionar conflictos socio- ambientales de los pueblos indígenas}

Otra característica frecuente en los conflictos socio-ambientales vinculados a los derechos de los pueblos indígenas es la poca capacidad del gobierno nacional para prevenir o gestionar dichos conflictos. Prevenir en términos de atacar a las causas estructurales del conflicto, ${ }^{59}$ pero también, en lo que toca a los órganos estatales, actuando de buena fe y con el ánimo positivo de cumplir con los mandatos de la Constitución, e interpretando los derechos de los pueblos indígenas a la luz de los instrumentos internacionales de derechos humanos ${ }^{60}$. En relación a la gestión del conflicto, la poca capacidad o voluntad política para transformarlos en acuerdos o políticas estatales adecuadas, resulta en muchas oportunidades en que el conflicto se

${ }^{56}$ Cfr. Ley 180 de 24/10/2011. No obstante, esta ley ha sido puesta en cuestión por la Ley 222 de 10/02/2012 que convoca a una consulta previa a los pueblos indígenas habitantes del TIPNIS para definir si la carretera debe pasar o no por el Parque Nacional y Territorio Indígena, lo que ha motivado la realización de una nueva marcha de las organizaciones indígenas a la ciudad de La Paz (IX Marcha), exigiendo el respeto a la Ley 180.

${ }^{57}$ Cfr. Defensoría del Pueblo, Informe Defensorial respecto a la violación de los derechos humanos en la Marcha Indigena, La Paz, noviembre de 2011.

${ }^{58}$ Ver acápite III. 4. de esta investigación.

${ }^{59}$ Cfr. Fundación UNIR, Las piezas del conflicto, prólogo de Ana María Romero de Campero, Ed. Plural, 2005.

${ }^{60}$ Este ánimo y voluntad políticos han estado ausentes en varias declaraciones del Presidente del Estado y de otras autoridades públicas en relación a la naturaleza e importancia de la consulta previa a los pueblos indígenas, siendo que se la ha estigmatizado como un obstáculo a las inversiones en el país. Ver acápite III.3. de esta investigación. 
prolongue desmesuradamente, por meses o años, pudiendo degenerar en situaciones de violencia y en un clima cada vez más agresivo y confrontacional entre unos y otros actores. Si bien el conflicto es sustancial a la vida en democracia ${ }^{61}$, una posición de celebración del conflicto $^{62}$ por parte de los actores estatales ${ }^{63}$ puede llevar a un escalamiento y profundización de los mismos que comprometa los derechos de los pueblos indígenas y la posibilidad de hacer una gestión pública proactiva de parte del gobierno.

Los tres casos de conflictos socio-ambientales que hemos revisado en este apartado, son una muestra de la deficiente gestión del conflicto por parte de actores estatales o privados. En el caso de Corocoro, desde 2008 hasta la fecha, este conflicto sigue abierto, y el pueblo originario del Jach'a Suyu Pakajaqi mantiene su exigencia al gobierno nacional respecto a la realización de la consulta previa. Por su parte, el conflicto entre la APG IG - Repsol, solo se pudo resolver luego de seis años de negociaciones, rompimientos de conversaciones y acciones de hecho por parte de la organización indígena, y sin una participación relevante del Estado como garante de los derechos de los pueblos indígenas. En tanto que, en el caso del TIPNIS el conflicto se mantiene abierto, desarrollándose a momento de escribir este documento (mayo de 2012), una nueva Marcha Indígena (la IX Marcha) que reclama el respeto y vigencia plena de la Ley 180, de protección del Territorio Indígena y Parque Nacional Isiboro Sécure, y la abrogación de la ley $222 .^{64}$

\section{Los acuerdos a los que se llegan para la resolución de los conflictos, con frecuencia, no son firmes}

En muchos casos, los acuerdos a los que se llegan para la resolución de los conflictos socio-ambientales vinculados a los derechos de los pueblos indígenas no son firmes, existiendo en varios casos, como veremos a continuación, poco respeto y buena fe de

\footnotetext{
${ }^{61}$ Fundación Unir, op. cit., p. 8.

${ }^{62}$ Reflexión de Jorge Komadina en una entrevista realizada por el autor para esta investigación, en $18 / 05 / 2012$.

${ }^{63}$ El Vicepresidente del Estado boliviano, Álvaro García Linera, ha señalado en mayo de 2012, en relación a la escalada de conflictos que vivió el país por esas semanas, que: (...) No hay que temerle (a los conflictos), la vida es conflicto, es lucha permanente. (...) Vamos a administrarlos, no se olviden que la lucha es nuestro reposo, vivimos y descansamos con la lucha (....) En: La Razón, Animal Político, $13 / 05 / 2012$.

${ }^{64}$ En el acápite siguiente se explica los alcances de esta ley.
} 
parte de los actores gubernamentales para honrarlos y cumplir con sus obligaciones estatales. Ello, a mediano y largo plazo, mantiene latentes las causas y las demandas relacionadas con el conflicto, con el agravante de exacerbar y polarizar las posiciones de los actores.

Los casos de Corocoro y del TIPNIS grafican muy bien esta característica. En relación al primer conflicto, cabe señalar que en noviembre de 2009, autoridades de COMIBOL y del Ministerio de Minería y Metalurgia, firmaron un Acuerdo con el Jach'a Suyu Pakajaqi para la realización del proceso de consulta previa en relación al funcionamiento del Complejo Hidrometalúrgico de Corocoro ${ }^{65}$, acuerdo que en los siguiente meses fue incumplido por los actores estatales, lo que retrotrajo las demandas de la organización indígena a su etapa inicial.

En el caso del TIPNIS, luego de que la VIII Marcha Indígena llegara a La Paz en octubre de 2011, el gobierno acogió la demanda de los/as marchistas y promulgó la Ley $\mathrm{N}^{\mathrm{o}} 180$ de protección del Territorio Indígena y Parque Nacional Isiboro Sécure, incluyendo una norma específica que dispone que ni la carretera Villa Tunari-San Ignacio de Moxos ni ninguna otra puede atravesar el TIPNIS. No obstante ello, a menos de cuatros meses de la promulgación de dicha norma, en febrero de 2012, el gobierno promulgó una nueva Ley (Ley $\mathrm{N}^{\circ}$ 222) que reabrió el conflicto del TIPNIS, condicionando la suerte de la construcción de la carretera a través del TIPNIS a un proceso de consulta inconstitucional, pues ya no sería previo respecto a actos administrativos consumados por parte del gobierno. Este doblez de parte del gobierno, ha motivado que organizaciones indígenas de tierras bajas y altas inicien una nueva marcha a La Paz (IX Marcha Indígena), exigiendo el cumplimiento de la Ley No 180.

\section{ROL DESEMPENAADO POR LA JUSTICIA CONSTITUCIONAL PARA GARANTIZAR LOS DERECHOS DE LOS PUEBLOS INDÍGENAS EN CONFLICTOS SOCIO-AMBIENTALES}

Como se ha visto en el apartado anterior de este trabajo, existe un incremento y profundización de los conflictos socio-ambientales que afectan a los pueblos indígenas en el país, y al mismo tiempo, se ha manifestado que las organizaciones indígenas, en

${ }^{65}$ Cfr. VARGAS, M., "Demanda de Consulta previa en territorio Jach'a Suyu Pakajaqi”, en Revista Artículo Primero: Industrias Extractivas. Politicas y Derechos, Año 14, No 21, Santa Cruz, 2011. 
general, no identifican a las acciones judiciales como una vía para la tutela de sus derechos y la resolución de sus conflictos, apelando de modo preponderante a las acciones directas de hecho para la consecución de tales fines. Con estos antecedentes, en el presente acápite se analizarán las limitaciones y aciertos que ha tenido la Justicia Constitucional (JC) para proteger los derechos de los pueblos indígenas en el país, en lo que vamos a denominar como su primer período de funcionamiento (de 1999 a 2011), y ello, principalmente, a partir del análisis de algunas de sus resoluciones pero también de algunas de las características del funcionamiento de la Justicia Constitucional y de su contexto político y social. Todo esto servirá como insumo para sugerir algunas recomendaciones orientadas a fortalecer el rol de la JC en la tutela de los derechos indígenas, al final de este trabajo.

\section{Naturaleza y función de la Justicia Constitucional en Bolivia}

El Tribunal Constitucional Plurinacional vela por la supremacía de la Constitución, ejerce el control de constitucionalidad, y precautela el respeto y la vigencia de los derechos y las garantías constitucionales ${ }^{66}$. Ello se realiza, conforme a la doctrina constitucional, ${ }^{67}$ a través: del control normativo (v.g. control de constitucionalidad de leyes, decretos y resoluciones); el control del ejercicio del poder político (v.g. en casos de conflictos de competencias y atribuciones de los órganos estatales, usurpación de funciones de funcionarios públicos, etc.); y el control tutelar efectivo, inmediato e idóneo de los derechos y garantías constitucionales de las personas. Siendo la más importante de sus funciones la tutela de los derechos fundamentales ${ }^{68}$, que es a la vez la primera función del Estado. La Justicia Constitucional se operativiza a través de las Garantías Jurisdiccionales Constitucionales como: la Acción de Libertad, de Amparo Constitucional, de Protección de Privacidad, de Inconstitucionalidad, la Acción Popular, la Acción de Cumplimiento, y el Recurso Directo de Nulidad.

El sistema de control constitucional boliviano corresponde a un sistema mixto. La Justicia Constitucional es ejercida por el Tribunal Constitucional Plurinacional (TCP),

\footnotetext{
${ }^{66}$ Cfr. Artículo 196 de la Constitución Política del Estado.

${ }^{67}$ Cfr. RIVERA SANTIVAÑEZ, J., A., Jurisdicción constitucional. Procesos constitucionales en Bolivia, Ed. Kipus, $3^{\text {a }}$ ed., Cochabamba, 2011, pp. 16 y 17

${ }^{68}$ Cfr. Artículo 1, de la Ley No 27 - Ley del Tribunal Constitucional Plurinacional. Ver también DERMISAKY, P., Justicia Constitucional y Estado de Derecho, 2a ed., Ed. Alexander, 2005, La Paz.
} 
en ensamble con los juzgados y tribunales competentes de la jurisdicción ordinaria (v.g. Sala de turno de los Tribunales Departamentales de Justicia, juzgados de materia o juzgados mixtos) que conocen las acciones de Libertad, Amparo Constitucional, Protección de Privacidad, Acción Popular, y de Cumplimiento, y remiten de oficio sus resoluciones ante el Tribunal Constitucional para su revisión. El TCP resuelve aprobando o revocando la resolución del Tribunal o Juzgado remitente. Es importante enfatizar que cuando los Tribunales o juzgados de naturaleza ordinaria conocen las Acciones Constitucionales ${ }^{69}$ se revisten del carácter de Tribunales de Garantías Constitucionales, y sus resoluciones son obligatorias y de inmediato cumplimiento (la revisión de la resolución elevada ante el TCP no limita la vinculatoriedad e inmediato cumplimiento de la misma).

\section{Creación de la Justicia Constitucional y primer periodo de funcionamiento}

La institución del Tribunal Constitucional (TC) se crea a través de la reforma constitucional de 1994 (mediante Ley $\mathrm{N}^{\mathrm{o}} 1585$ de 12/08/1994). Los primeros Magistrados del TC son elegidos por el Congreso Nacional, casi cuatro años después de la creación del Tribunal, el 24/07/1998, y son posesionados en 5 de agosto de ese mismo año. Concluida la fase de organización y de logística interna, el TC inicia sus funciones en $1 / 06 / 1999^{70}$.

A los efectos de este trabajo, consideraremos como el primer período de funcionamiento del Tribunal Constitucional al que va de 1/06/1999 al 31/12/2011, fecha hasta la que funcionó el TC en el marco de la Reforma Constitucional de 1994 (y reformas constitucionales posteriores de 2004 y 2005). Cabe señalar, que a partir del 3/01/2012 inicia su funcionamiento el nuevo Tribunal Constitucional Plurinacional (TCP), en el marco de la Constitución de 2009, con la posesión de los/as nuevos/as Magistrados. En los últimos años del primer período de funcionamiento, el TC sufrió una fuerte crisis institucional que describiremos sucintamente en las siguientes líneas, ya que aporta elementos valiosos para realizar la valoración de esta primera etapa de su funcionamiento.

\footnotetext{
${ }^{69}$ Cfr. Artículo 2 de la Ley No 27.

${ }^{70}$ Cfr. DERMISAKY, P., op. cit., p. 82.
} 
En 2007, durante el primer mandato del Presidente Evo Morales, se produce una fuerte tensión entre el Poder Ejecutivo y varios miembros del Tribunal Constitucional. El gobierno considera que la mayoría de los/as Magistrados del TC tiene afinidad con partidos políticos de la oposición ${ }^{71}$ (lo que es rechazado por los Magistrados). El Poder Ejecutivo plantea una demanda por prevaricato contra varios de los miembros del TC. Hasta febrero de 2008, cuatro de los cinco Magistrados/as del TC renuncian dejando sin quórum al órgano de control constitucional. En mayo de 2009, renuncia la última de las Magistradas del TC. Las Magistradas argumentan como razones para su renuncia la presión y maltrato del Poder ejecutivo contra el TC y sus miembros ${ }^{72}$. Durante dos años (gestiones 2008 y 2009), el TC se encuentra prácticamente inoperativo, lo que ocasiona un grave daño al estado de derecho, al control normativo de constitucionalidad, al equilibrio de poderes del Estado, y la tutela de derechos y garantías constitucionales de las personas.

En febrero de 2010, se aprueba la Ley $\mathrm{N}^{\mathrm{o}} 3$, por la que se faculta al Presidente del Estado a designar de modo extraordinario Magistrados interinos del Tribunal Constitucional, así como, de instancias jerárquicas del órgano judicial. Ello, hasta tanto se elijan y posesionen a los/as nuevos miembros del Tribunal Constitucional Plurinacional y a Magistrados/as del órgano judicial. Esta medida resulta justificada debido a la enorme retardación de justicia generada por la crisis del TC y del órgano judicial. En 17/02/2010 se posesionan a los/as Magistrados/as interinos del TC elegidos por el Presidente. A momento de su posesión, los nuevos miembros del TC tenían un acumulado de 3.761 causas pendientes de resolución ${ }^{73}$.

Los/as Magistrados interinos del TC cesan en sus funciones el 31/12/2011, ${ }^{74}$ y en 3/01/2012 se posesionan a los/as Magistrados del nuevo Tribunal Constitucional

71 Cfr. http://www.lostiempos.com/diario/actualidad/nacional/20090527/el-tribunal-constitucional-debolivia-quedara-en-suspenso-hasta-proximo_11091_17974.html; y RODRÍGUEZ VELTZÉ, E., "Órgano judicial y Tribunal Constitucional Plurinacional"; en Miradas. Nuevo texto constitucional, Publicación de Idea Internacional, Universidad Mayor de San Andrés y Vicepresidencia del Estado Plurinacional, La Paz, 2010, p. 430.

${ }^{72} \mathrm{Cfr}$. http://www.mirabolivia.com/foro_total.php?id_foro_ini=15025

73 Cfr. http://www.caracol.com.co/noticias/el-tribunal-constitucional-inicia-sus-primeras-tareas/ 20100 219/nota/956009.aspx

${ }^{74}$ Ello, de acuerdo a la Ley $N^{0} 212$ de 23/12/2011 que dispone la conclusión de funciones y extinción institucional de la Corte Suprema de Justicia, Tribunal Agrario Nacional, Consejo de la Judicatura y Tribunal Constitucional el 31 de diciembre de 2011, para su reemplazo por el Tribunal Supremo de Justicia, el Tribunal Agroambiental, el Consejo de la Magistratura, y el Tribunal Constitucional Plurinacional, respectivamente, conforme a lo establecido por la nueva Constitución de febrero de 2009. 
Plurinacional, pre-seleccionados por la Asamblea Legislativa Plurinacional y electos por voto popular en octubre de 2011.

\section{Resoluciones del Tribunal Constitucional relacionadas con la tutela de los derechos de los pueblos indígenas}

En la revisión de la jurisprudencia del Tribunal Constitucional ${ }^{75}$, en su primer periodo de funcionamiento (1999-2011), no se ha identificado ninguna acción constitucional que haya sido planteada por organizaciones indígenas para prevenir o reparar daños socioambientales. De modo paradójico, sí se encontró un Amparo constitucional ${ }^{76}$ interpuesto por la empresa Transredes, responsable de uno de los peores derrames de petróleo en la historia del país (en el Río Desaguadero), contra varias autoridades del poder ejecutivo bolivianas, reclamando entre otros, su derecho a la seguridad jurídica, y solicitando la nulidad de la resolución ministerial que disponía la multa en contra de la empresa de transporte de hidrocarburos por este caso de contaminación.

En general, como reconoce el ex Magistrado del Tribunal Constitucional, José Antonio Rivera $^{77}$, han existido muy pocos casos que haya conocido el TC relacionados con la tutela de los derechos de los pueblos indígenas. En este acápite, analizamos dos de ellos, cuyos criterios de jurisprudencia se encuentran en las antípodas en relación al derecho de consulta previa de los pueblos indígenas. Se trata de la Sentencia constitucional (SC) 0045/2006 de 2/06/2006, y la SC 2003/2010-R de 25/10/2010.

- En la Sentencia Constitucional 0045/2006, se resuelve sobre un recurso abstracto de inconstitucionalidad interpuesto por Luis Siles Pérez, Diputado Nacional, que demanda la inconstitucionalidad de varios artículos de la Ley de Hidrocarburos $\mathrm{N}^{\mathrm{o}} 3058$ (de mayo de 2005), entre ellos, normas relacionadas con el derecho de consulta previa de los pueblos indígenas.

Es de destacar, en términos de jurisprudencia constitucional, el hecho de que la sentencia establece que los tratados e instrumentos internacionales en materia de derechos humanos suscritos, adheridos o ratificados por el país forman parte del bloque

\footnotetext{
75 A estos efectos se revisó la base de datos de Jurisprudencia en línea con que cuenta el Tribunal Constitucional de Bolivia, en su página web: http://www.tribunalconstitucional.gob.bo/ Revisión realizada en mayo de 2012 .

${ }^{76}$ Cfr. SC 0337/2007-R de 26/04/2007

${ }^{77}$ En entrevista personal realizada al ex Magistrado del Tribunal Constitucional, José Antonio Rivera, en $8 / 05 / 2012$.
} 
de constitucionalidad, teniendo aplicación directa en el ámbito nacional. Dicha sentencia cita como antecedente de esta línea jurisprudencial a las sentencias: SC 1420/2004-R y la SC 1662/2003-R del TC. Esta última sentencia sobre el particular dispone:

“(...) este Tribunal Constitucional, realizando la interpretación constitucional integradora, en el marco de la cláusula abierta prevista por el art. 35 de la Constitución, ha establecido que los tratados, las declaraciones y convenciones internacionales en materia de derechos humanos, forman parte del orden jurídico del sistema constitucional boliviano como parte del bloque de constitucionalidad, de manera que dichos instrumentos internacionales tienen carácter normativo y son de aplicación directa (...)"

De modo expreso, la Sentencia 45/2006 señala que el Convenio 169 de la OIT, ratificado por Bolivia mediante Ley 1257, de 11 de julio de 1991, forma parte del bloque de constitucionalidad boliviano. Cabe señalar, que este reconocimiento es muy importante y garantista de los derechos humanos de los pueblos indígenas, ya que en ese entonces (junio 2006), la Constitución vigente no reconocía de modo expreso el carácter de norma constitucional de los tratados de derechos humanos suscritos por el país.

Desafortunadamente, el Tribunal Constitucional con muy poco conocimiento sobre la naturaleza y alcance de los derechos de los pueblos indígenas contenidos en el Convenio 169, y en todo caso, tergiversando el sentido de la norma internacional, en relación al artículo sobre el derecho a la consulta previa contenido en la Ley de Hidrocarburos 3058 señala que:

“al establecer (la ley de hidrocarburos) que dicha consulta tiene por objeto, además de determinar la afectación a los intereses de los pueblos indígenas o campesinos, lograr su consentimiento, se margina de lo dispuesto por el bloque de constitucionalidad, pues como ya fue analizado, el referido art. 15.2 del Convenio 169 de la OIT, no tiene ese objeto, máxime cuando, como ya fue expuesto, los hidrocarburos son de propiedad del Estado" (Los resaltados son del autor).

En consecuencia, el TC evidencia una visión restrictiva y equivocada sobre los alcances del derecho de consulta previa de los pueblos indígenas, máxime si entendemos que la consulta previa, lejos de ser un acto meramente procedimental o ritual, debe desarrollarse desde su preparación, ejecución y conclusión con el ánimo y finalidad de 
llegar a un acuerdo o lograr el consentimiento (de los pueblos indígenas) acerca de las medidas propuestas, como expresamente dispone el artículo 6.2 del Convenio 169. Por otra parte, la Sentencia establece:

“(...) la norma analizada (el Artículo 15.2 del Convenio 169) impone el deber de consultar cuál el daño que pueden sufrir sus intereses, para que sea debida y equitativamente indemnizado; por tanto, la consulta no puede ser entendida como la solicitud de una autorización sino como un acto efectivo de consultar a los pueblos indígenas $\mathrm{y}$ tribales asentados en los territorios objeto de la explotación sobre la cuantificación del daño a sus intereses, que sufrirán como efecto de dicha extracción; y mucho menos puede ser entendida como una facultad para impedir la explotación de la riqueza del subsuelo que pertenece al Estado (...)" (Los resaltados son del autor).

Entonces, queda clara la noción reduccionista de esta sentencia constitucional sobre el contenido y alcance del derecho de consulta, que en el marco de los derechos territoriales del pueblo indígena debe permitirle expresar si está de acuerdo o no con el emprendimiento extractivo, y en su caso, si el mismo debería contemplar cambios, modificaciones o mejoras para prevenir daños a sus derechos. Desde ya, es errado llegar a pensar que el derecho de consulta en el Convenio 169 asuma una mera visión monetarista que se limite al cálculo del pago por los daños y perjuicios que se les vaya a ocasionar a los pueblos indígenas con las actividades extractivas.

En una manifestación carente de fundamento legal y prepotente, el TC señala que no sería admisible una respuesta negativa de los pueblos indígenas en la consulta previa, y declara la inconstitucionalidad parcial del artículo 116 de la Ley de Hidrocarburos:

\footnotetext{
“(...) es necesario también declarar la inconstitucionalidad de la frase: "En caso de tener la consulta, reconocida en el artículo 115, un resultado negativo", del art. 116 de la LH, pues dicho resultado negativo no será posible, y resulta también contrario al bloque de constitucionalidad (...)”.
}

Esta sentencia del TC atenta no sólo contra el espíritu del derecho de consulta, sino contra derechos humanos de primera generación, como el derecho a la libertad de pensamiento y opinión. Resulta extraño que el órgano garante de los derechos constitucionales no solo haya incumplido con su mandato, sino que vulnere derechos constitucionales de los pueblos indígenas con recortes legales como los señalados. 
Finalmente, el TC dispone declarar la inconstitucionalidad parcial del artículo 115 de la Ley de Hidrocarburos, en cuanto a la finalidad de la consulta previa de lograr el consentimiento de los pueblos indígenas.

- En 25 de octubre de 2010, el TC emite la Sentencia Constitucional 2003/2010-R relacionada con el derecho de consulta previa de los pueblos indígenas, cuyo criterio de jurisprudencia se encuentra en la antípoda de la primera sentencia analizada. Cabe señalar, que este caso no se inicia con la acción de una organización indígena para exigir el cumplimiento de su derecho de consulta previa, sino, con un Amparo constitucional planteado por la representante de una instancia estatal, el Servicio Departamental de Caminos (SEDECA) Tarija, contra la Asamblea del Pueblo Guaraní Itika Guasu (APG IG), acusándola de vulnerar su derecho de reunirse y asociarse para fines lícitos y para el trabajo. Ello por cuanto, la APG IG cometió el "despropósito" de expresar en una carta enviada a la empresa Petrosur SRL, su no conformidad con un convenio firmado entre SEDECA y Petrosur SRL, para la refacción y ocupación de un campamento de trabajadores petroleros ubicado en territorio de la APG IG, sin la realización de la consulta previa a la organización indígena.

La Jueza Técnico del Tribunal de Sentencia de la provincia O'Connor de Tarija (Tribunal de Garantías Constitucionales), en febrero de 2008, concedió la tutela solicitada por SEDECA, disponiendo que el representante de la Asamblea del Pueblo Guaraní deje sin efecto la carta remitida a Petrosur SRL.

Debido a la crisis institucional que afectó al TC por esos años, y una vez posesionados sus Magistrados interinos, el TC recién revisa la resolución correspondiente a este caso en octubre de $2010^{78}$, revocando la Resolución del Tribunal de garantías, y exhortando al órgano ejecutivo a efectivizar el derecho a la consulta de las naciones y pueblos indígena originario campesinos, de conformidad a los fundamentos de esta Sentencia.

La SC se remite a la regulación de la consulta previa en el Convenio 169, así como, a la Declaración de las Naciones Unidas sobre los Derechos de los Pueblos Indígenas ${ }^{79}$, ratificada por Bolivia mediante Ley 3760 de 7/11/2007, la cual en su artículo 19

\footnotetext{
${ }^{78}$ Cabe señalar la poca utilidad, en relación al caso específico, de una sentencia constitucional (SC) pronunciada más de dos años y medio después de que la Resolución del Tribunal de Garantías desconociese el derecho a la consulta previa de la APG IG. No obstante ello, como se señala en líneas posteriores, la SC tiene una gran importancia en términos de precedente de jurisprudencia constitucional.

${ }^{79}$ La SC manifiesta que tales instrumentos internacionales forman parte del bloque de constitucionalidad, de modo congruente con lo establecido por la nueva Constitución de 2009.
} 
establece que: "Los Estados celebrarán consultas y cooperarán de buena fe con los pueblos indígenas interesados por medio de sus instituciones representativas antes de adoptar y aplicar medidas legislativas y administrativas que los afecten, para obtener su consentimiento libre, previo e informado" (los resaltados son del autor). Por otra parte, se remite al artículo 30, II, 15) de la nueva Constitución, también sobre el derecho a la consulta de los pueblos indígenas, y al artículo 403 de la $\mathrm{CPE}$, que reconoce la integralidad del territorio indígena originario campesino.

A diferencia de lo señalado en la SC 45/2006, el TC establece que la finalidad de la consulta previa es llegar a un acuerdo o lograr el consentimiento del pueblo indígena, de modo congruente con lo establecido por el Convenio 169 y por la Declaración de las Naciones Unidas sobre los Derechos de los Pueblos Indígenas. La SC, asimismo, identifica tres casos en los que el consentimiento del pueblo indígena es imprescindible para poder continuar con las iniciativas propuestas por el Estado.

La consulta referida debe ser desarrollada con la finalidad de lograr un acuerdo con los pueblos o su consentimiento libre, previo e informado. Ahora bien, cabe aclarar que este consentimiento se constituye en una finalidad de la consulta, pero no un derecho en sí mismo, salvo en las dos situaciones previstas tanto en el Convenio 169 como en la Declaración de las Naciones Unidas sobre los derechos de los pueblos indígenas: 1. Traslados de las tierras que ocupan y su reubicación (arts. 16.2 del Convenio 169 y 10 de la Declaración de las Naciones Unidas sobre los Derechos de los Pueblos Indígenas); y, 2. Almacenamiento o eliminación de materiales peligrosos en las tierras o territorios de los pueblos indígenas (art. 29 de la Declaración).

A los dos supuestos anotados, debe añadirse un tercero, que fue establecido jurisprudencialmente por la Corte Interamericana de Derechos Humanos en el Caso del Pueblo Saramaka v. Surinam, en el que reconoció el derecho al consentimiento " $(. .$.$) cuando se trate de planes de desarrollo o de inversión a$ gran escala que tendrían un mayor impacto dentro del territorio Saramaka, el Estado tiene la obligación, no sólo de consultar a los Saramakas, sino también debe obtener el consentimiento libre, informado y previo de éstos, según sus costumbres y tradiciones. La Corte considera que la diferencia entre "consulta" y "consentimiento" en este contexto requiere de mayor análisis" (...) lo que significa que en dichos casos los pueblos tienen la potestad de vetar el proyecto. (Los resaltados son del autor). 
Consideramos importante destacar dos elementos en la cita anterior. Por una parte, el hecho de que el TC reconozca a la jurisprudencia de la Corte Interamericana de Derechos Humanos como fuente del derecho y de la jurisprudencia internos. ${ }^{80} \mathrm{Y}$ por otra, que se subraye con claridad los casos específicos en que es imprescindible el consentimiento de los pueblos indígenas, que cuando resulte en una respuesta negativa importará el veto del proyecto o iniciativa. La SC es especialmente esclarecedora y oportuna, en un contexto en el que el órgano ejecutivo tiene tantos reparos y dificultades, ya no solo para reconocer que la finalidad de la consulta es el consentimiento, si no, para admitir el derecho de consulta de los pueblos indígenas en sí mismo ${ }^{81}$.

En los casos no alcanzados por la necesidad imprescindible del consentimiento, rige desde ya, la obligación del Estado de realizar la consulta previa con la visión y el ánimo de llegar a un acuerdo con el pueblo indígena, respetando sus derechos e instituciones propias. De no llegarse a un acuerdo, habría que seguir lo enunciado por el artículo 116 de la Ley de Hidrocarburos 3058; esto es, el Estado debería promover un proceso de conciliación con la organización indígena basado en el mejor interés nacional.

El criterio jurisprudencial contemplado en la SC 2003/2010-R marca un hito sobre el contenido y alcances del derecho de consulta previa en el país; y de modo específico, por la vinculación de la consulta con el otorgamiento del consentimiento por parte del pueblo indígena, criterio que debe ser tenido como base y precedente en posteriores resoluciones del Tribunal Constitucional, así como, por los otros órganos del Estado en

\footnotetext{
${ }^{80}$ El Magistrado relator de la SC 2003/2010-R, Marco Antonio Baldivieso Jinés, en una ponencia de marzo 2012, explica sobre los fundamentos de la SC “que las autoridades bolivianas, los tribunales, los jueces están obligados a cumplir la jurisprudencia, las sentencias de la Corte Interamericana de Derechos Humanos". Y ello, en razón a que Bolivia ha ratificado la Convención Americana de Derechos Humanos, a través de Ley 1430 de 11/02/1993, "reconociendo también a la Corte Interamericana de Derechos Humanos como el interprete de este instrumento regional”. Cfr. Marco Antonio Baldivieso Jinés, "La Sentencia Constitucional 2003/2010-R - Itika Guasu y sus consecuencias para el Derecho a la Consulta en Bolivia". Ponencia realizada en el Taller para periodistas "La Consulta Previa, Libre e informada para Pueblos Indígenas", organizado por CEADESC en 9 de marzo 2012. En similar sentido, la sentencia constitucional $0110 / 2010-\mathrm{R}$ ha señalado en relación a la vinculatoriedad interna de las sentencias de la CIDH que “...se colige que inequívocamente las Sentencias emanadas de la CIDH, por su naturaleza y efectos, no se encuentran por debajo ni de la Constitución Política del Estado tampoco de las normas jurídicas infra-constitucionales, sino por el contrario, forman parte del bloque de constitucionalidad y a partir del alcance del principio de supremacía constitucional que alcanza a las normas que integran este bloque, son fundamentadoras e informadoras de todo el orden jurídico interno". Citado por Boris Arias López, Estado de transición constitucional y nuevas líneas jurisprudenciales del Tribunal Constitucional Boliviano.

${ }^{81}$ Ver acápites III.3 y III.6 de esta investigación.
} 
relación a todo acto administrativo o medida legislativa que pueda afectar a los pueblos indígenas.

- Finalmente, es importante manifestar que en este primer periodo de funcionamiento del TC, en las sentencias constitucionales primó un criterio iusprivatista ${ }^{82}$ en cuanto a la consideración de las personas que tenían legitimación activa ${ }^{83}$ para interponer acciones como la del amparo constitucional. En consecuencia, el TC consideraba que sólo podían interponer acciones de tutela constitucional quienes tuviesen un interés directo, específico e individual sobre el objeto de la demanda, lo que puede haber dejado por fuera demandas relacionadas con derechos colectivos, de naturaleza transindividual, como el derecho al ambiente equilibrado o el derecho a las formas de desarrollo propias de los pueblos indígenas. Ello, junto a otros factores ${ }^{84}$, puede ayudar a explicar porqué no se ha identificado ninguna acción constitucional interpuesta por organizaciones indígenas para la tutela de sus derechos en casos de daños o conflictos socioambientales, en el periodo revisado. ${ }^{85}$

\section{Valoración de la Justicia Constitucional en el período revisado}

A continuación, se realiza una valoración sobre algunos avances y dificultades de la Justicia Constitucional en el período 1999-2011, elementos que servirán como insumo para la realización de recomendaciones de cara al funcionamiento del nuevo Tribunal Constitucional Plurinacional y de los Tribunales de Garantías Constitucionales, ello, en el último acápite de este trabajo.

- Las acciones constitucionales no se han constituido en una herramienta de tutela usada por los pueblos indígenas para la prevención o reparación de daños socio-ambientales en sus territorios. Algunos técnicos de las organizaciones indígenas consideran que las

\footnotetext{
${ }^{82}$ Ello, con excepción de las acciones populares planteadas a la Justicia Constitucional partiendo de los derechos y garantías reconocidos por la nueva Constitución. Aspectos que serán analizados en un acápite posterior de esta investigación.

${ }^{83}$ Esto es, la capacidad procesal para ser parte demandante en un proceso judicial.

${ }^{84}$ Ver el siguiente acápite de esta investigación.

${ }^{85}$ En relación a este criterio restrictivo de legitimación activa, la SC 134/2002-R, citada por José Antonio Rivera, establece que: "la legitimación activa en el Amparo corresponde al afectado que directamente acredita interés en el asunto y en quién recaen las consecuencias jurídicas de la resolución o acto de la autoridad que se impugna". Ver una similar interpretación en relación a la legitimación activa en la SC 1732/2003-R, y el Auto Constitucional 0181/2010-CA.
} 
acciones antes los jueces son lentas, costosas y muy burocráticas ${ }^{86}$, por tanto, no se las asume como parte del repertorio de acciones de incidencia para la tutela de sus derechos. La desconfianza en la justicia constitucional y en la justicia ordinaria es generalizada en el país, según una encuesta de $2011^{87}$, casi 8 de cada 10 bolivianos (de la población urbana) desconfiaban de la Corte Suprema de Justicia (actual Tribunal Supremo de Justicia), y del Tribunal Constitucional (actual Tribunal Constitucional Plurinacional).

- Con excepción de la SC 2003/2010-R, la línea jurisprudencial del TC ha sido restrictiva en relación al contenido y alcances de los derechos de los pueblos indígenas. De modo adicional al derecho de consulta previa, objeto de las sentencias analizadas en este trabajo, el TC asumió también criterios restrictivos en torno al reconocimiento y validez de las actuaciones de la Justicia Indígena. ${ }^{88}$ En suma, dichos criterios han patentizado un débil conocimiento y escasa sensibilidad e internalización de la cosmovisión, los problemas y derechos de los pueblos indígenas por parte de los/as Magistrados del TC.

- Han existido sentencias constitucionales y resoluciones del TC que rayan en la arbitrariedad e inconstitucionalidad, inconcebibles en el órgano guardián de los derechos y garantías fundamentales de las personas. ${ }^{89}$ Prácticas de este tipo contribuyen a profundizar la desconfianza, la debilidad del estado de derecho, y el escepticismo de los ciudadanos sobre el rol y razón de ser del TC. Es imperativo que la Justicia Constitucional desarrolle líneas jurisprudenciales congruentes con el respeto a los derechos humanos fundamentales, y en especial, con los derechos de los pueblos indígenas. Por otra parte, resulta imprescindible que la JC asuma como parte de sus

\footnotetext{
${ }^{86}$ Entrevista personal con Betzabeth Puma Zárate, Técnica de apoyo en temas legales de la Asamblea del Pueblo Guaraní, en mayo de 2012.

${ }^{87}$ Cfr. Consorcio Iberoamericano de Investigación de Mercados y Asesoramientos (CIMA), Barómetro Iberoamericano de Gobernabilidad 2011. En el caso de Bolivia, dicha encuesta sólo tomó en cuenta la población urbana del país.

${ }^{88}$ Cfr. VARGAS, CH., I.M., “Justicia indígena y jurisdicción constitucional: Bolivia, 2003-2005”, en Derechos Humanos y Acción Defensorial. Revista Especializada del Defensor del Pueblo en Bolivia, núm. 1, 2006.

${ }^{89}$ De modo adicional a la SC 45/2006, que establece la imposibilidad de un resultado negativo en la consulta previa, y por tanto, que los pueblos indígenas puedan disentir del proyecto/iniciativa consultado; cabe mencionar, que el TC en su momento dispuso no conocer, por una nueva "política institucional", varias acciones de amparo constitucional relacionadas con el incumplimiento de resoluciones judiciales firmes. Con ello, se vulneró de modo palmario el derecho a la protección judicial de los afectados/as. Ver al respecto IBARGÜEN B. G., "Restricciones de Acceso a la Justicia Constitucional", en Derechos Humanos y Acción Defensorial. Revista Especializada del Defensor del Pueblo en Bolivia, núm. 1, 2006.
} 
funciones la rendición de cuentas regular sobre la razonabilidad y raigambre constitucional de sus decisiones ante la sociedad civil. Ello, contribuirá al fortalecimiento de su legitimidad, su sostenibilidad institucional e independencia de otros órganos estatales.

- De modo relacionado con el punto anterior, la justicia constitucional (TC y Tribunales de garantías constitucionales) ha desarrollado acciones insuficientes de educación e información sobre la naturaleza, importancia y funciones de la Justicia constitucional que puedan llegar a segmentos vulnerables de la población boliviana, como son los pueblos indígenas.

- El TC asumió un criterio "iusprivatista" en cuanto al otorgamiento de legitimación activa, lo que ha podido tener un efecto disuasivo y limitante en cuanto a la interposición de acciones para la tutela de derechos colectivos, en los que el afectado/a no cuenta con un derecho exclusivo o divisible sobre el bien jurídico protegido.

- La profunda crisis institucional que afectó al TC de 2007 a 2009, dejó en situación de indefensión a miles de litigantes vulnerándose sus derechos y garantías fundamentales por el propio Estado. Por otra parte, cabe señalar que el conflicto de poderes que se dio entre el órgano ejecutivo y el TC, dañó severamente los principios democráticos de independencia y equilibrio de poderes en el país, principios que resulta imprescindible reestablecer entre el nuevo Tribunal Constitucional Plurinacional y los demás órganos estatales.

- La SC 2003/2010-R genera una nueva línea jurisprudencial en materia del derecho a la consulta previa de los pueblos indígenas de modo congruente con la nueva Constitución de 2009 y los instrumentos internacionales sobre pueblos indígenas que forman parte del bloque de constitucionalidad. Este nuevo criterio jurisprudencial, en relación a la consulta previa y los casos en los que debe concurrir de modo imprescindible el consentimiento del pueblo indígena, debería considerarse como una línea de base para posteriores sentencias constitucionales relacionadas con tales derechos, y asimismo, debería ser respetado en sus alcances e interpretación por los demás órganos del Estado.

- Actores importantes de la sociedad civil boliviana, como organizaciones sociales, ONGs, periodistas, la academia, etc., no han jugado un rol relevante en la exigencia de transparencia y rendición de cuentas a la Justicia Constitucional; así como, para 
promover el rol de la JC en la prevención y resolución de conflictos socio-ambientales que afectan a los pueblos indígenas.

\section{CONSTITUCIÓN DE 2009 Y NUEVAS ACCIONES CONSTITUCIONALES}

\section{Principales características de la nueva Constitución Política del Estado}

Luego de un proceso de Asamblea Constituyente muy conflictivo y que polarizó a varios sectores de la sociedad civil boliviana, en enero de 2009 se aprobó el nuevo texto constitucional a través de un Referéndum popular que contó con el $61 \%$ de votos favorables de los bolivianos/as.

La nueva Constitución contempla un cambio en la forma del Estado boliviano ${ }^{90}$, de un Estado unitario centralizado, a un Estado unitario, plurinacional, descentralizado y con autonomías; esto es, autonomías departamentales, municipales, indígena originaria campesinas y regionales.

Esta Constitución se distingue también por incorporar un muy amplio catálogo de derechos y garantías. Entre ellos, derechos de tercera generación como el derecho al agua, y al medio ambiente saludable, protegido y equilibrado. Vinculado a este último derecho se otorga tutela constitucional a los derechos de las generaciones futuras, y a los seres vivos que son reconocidos como bienes jurídicos per $s e^{91}$. Cabe destacar, por otra parte, el reconocimiento de legitimación activa amplia en favor de cualquier persona, para proteger el derecho al ambiente a través de acciones legales pertinentes ${ }^{92}$. Dicho reconocimiento, constituye un avance muy importante del derecho constitucional boliviano para brindar tutela efectiva a los derechos colectivos, que de modo previo a la Constitución de 2009 era inviable, ya que la legitimación activa estaba pensada únicamente para la tutela de intereses privados.

Asimismo, se debe subrayar la importancia de todo un capítulo destinado al reconocimiento de varios derechos colectivos a favor de los pueblos indígenas, entre ellos, el derecho a la gestión territorial autónoma, el derecho a la identidad cultural y al

\footnotetext{
${ }^{90}$ Un cambio en la relación entre poder y territorio, en la clasificación de formas de Estado planteada por Germán Bidart Campos, que gira hacia la descentralización política del país, a través de la creación de las autonomías subnacionales. Cfr. BIDART CAMPOS, G., Tratado elemental del derecho constitucional argentino, Ed. Ediar, Buenos Aires, Nueva edición ampliada y actualizada a 1999-2000, Tomo I-A, 2000, p. 637.

${ }^{91}$ Cfr. Artículo 33 de la Constitución Política del Estado.

${ }^{92}$ Cfr. Artículo 34 de la Constitución Política del Estado.
} 
respeto de sus instituciones, cosmovisión y creencias, el derecho a la consulta previa y obligatoria, etc. $^{93}$

De modo correlativo al reconocimiento de derechos individuales y colectivos, la nueva Constitución mantiene -en base a los textos constitucionales precedentes- las garantías jurisdiccionales de: la acción de amparo constitucional, la acción de libertad (Habeas Corpus), la acción de inconstitucionalidad, la acción de protección de privacidad, y el recurso directo de nulidad; $y$, por otra parte, incorpora dos nuevas acciones constitucionales: la acción de cumplimiento y la acción popular. Siendo esta última, trascendental para la tutela de derechos colectivos, como será explicado en un acápite posterior.

Conforme se ha señalado antes ${ }^{94}$, la Constitución de 2009 es novedosa en su relación con el derecho internacional, ya que incorpora de modo expreso a los tratados e instrumentos internacionales de derechos humanos, suscritos o ratificados por el país, como parte del bloque de constitucionalidad, y asume el principio de favorabilidad, por el cual se aplica de modo preferente el derecho contemplado por el instrumento internacional, en caso de que éste sea más favorable a la persona o colectividad que el catálogo de derechos constitucionales.

En la nueva Constitución coexisten también ambigüedades y elementos contradictorios como el relacionado con la visión y modelo de desarrollo del país, que oscila entre el extractivismo y un modelo de desarrollo en equilibrio y respeto de los derechos individuales y colectivos de la población, asimismo, armónico con la preservación de la naturaleza y de la vida ${ }^{95}$.

En relación al órgano judicial, cabe relevar que se crea la Jurisdicción Agroambiental compuesta por el Tribunal Agroambiental y por los Juzgados Agroambientales, con competencias, entre otras, para prevenir daños o contaminación causada a diferentes elementos del ambiente, y establecer responsabilidades por los daños ocasionados para

\footnotetext{
${ }^{93}$ Cfr. Artículos 30 y siguientes de la Constitución Política del Estado.

${ }^{94}$ Sobre el particular, ver de modo complementario el acápite III.2.

${ }^{95}$ Así, el Artículo 356 de la Constitución dispone que: "Las actividades de exploración, explotación, refinación, industrialización, transporte y comercialización de los recursos naturales no renovables tendrán el carácter de necesidad estatal y utilidad pública" (el subrayado es del autor). Esto es, el otorgamiento del más alto interés estatal a las actividades extractivas, lo que en muchos casos podrá colisionar, por ejemplo, con el derecho al ambiente equilibrado y el correlativo deber ciudadano de protección y defensa del ambiente para el desarrollo de los seres vivos (Cfr. Artículos 33 y 108, incisos 14, 15 y 16 de la Constitución).
} 
la restauración, resarcimiento o reparación de los mismos ${ }^{96}$. Asimismo, se crea la Jurisdicción Indígena Originaria Campesina que aplica los principios, valores, normas y procedimientos propios de los pueblos indígenas, de modo congruente con los derechos y garantías establecidos en la Constitución. ${ }^{97}$

Por otra parte, la nueva Constitución contempla la creación del Tribunal Constitucional Plurinacional (TCP), compuesto por Magistrados/as con representación del sistema ordinario y del sistema indígena de justicia ${ }^{98}$. Se debe anotar que los/as Magistrados del TCP, junto a autoridades jerárquicas del órgano judicial, fueron electos por primera vez en la historia del país a través de voto popular, en octubre de 2011, de listas preseleccionadas por la Asamblea Legislativa Plurinacional. Tanto el proceso de preselección de candidatos/as como el de información a los votantes fueron cuestionados por partidos de oposición y por ciudadanos en general ${ }^{99}$, lo que resultó en la emisión de un alto porcentaje de votos nulos y blancos en dicha elección. Las/os nuevos Magistrados del TCP fueron posesionados en sus funciones en 3/01/2012.

\section{Nuevas acciones constitucionales para la tutela de derechos}

Se verá a continuación, de modo breve, elementos centrales a la naturaleza y alcances de la acción popular y de la acción de cumplimiento, recientemente reconocidas por la Constitución de 2009. A la par de identificar las posibilidades o limitaciones que conllevan para la tutela de los derechos de los pueblos indígenas vinculados a conflictos socio-ambientales, en el caso de la acción popular, se realizará un breve análisis de las primeras experiencias de su aplicación en el país.

\subsection{La acción popular}

\footnotetext{
${ }^{96}$ Cfr. Artículos 186 y siguientes de la Constitución, y artículos 134 y siguientes de la Ley No 25 - Ley del Órgano Judicial.

${ }^{97}$ Cfr. Artículos 190 y siguientes de la Constitución, y artículos 159 y siguientes de la Ley No 25 - Ley del Órgano Judicial.

98 Ver un análisis sobre el nuevo TCP en el marco de la Constitución de 2009, en RODRÍGUEZ VELTZÉ, E., "Órgano judicial y Tribunal Constitucional Plurinacional", en Miradas. Nuevo texto constitucional, Publicación de Idea Internacional, Universidad Mayor de San Andrés y Vicepresidencia del Estado Plurinacional, La Paz, 2010.

${ }^{99}$ Ver acápite II.4. de esta investigación.
} 
La acción popular es la garantía jurisdiccional constitucional de los nuevos derechos colectivos incorporados en la Constitución de 2009. La inclusión de esta acción en el texto constitucional puede permitir voltear la página de largos años de indefensión jurisdiccional de los derechos colectivos en el país.

\section{A. Objeto y naturaleza}

Conforme a la Constitución, la acción popular procede "contra todo acto u omisión de las autoridades o de personas individuales o colectivas que violen o amenacen con violar derechos e intereses colectivos, relacionados con el patrimonio, el espacio, la seguridad y salubridad pública, el medio ambiente y otros de similar naturaleza reconocidos por esta Constitución". 100

Entonces, cabe destacar que la finalidad de la acción popular es la tutela de los derechos colectivos, que se puede activar ante cualquier acción u omisión de autoridades o particulares que estén lesionando o haya riesgo de que lesionen los derechos colectivos. En consecuencia, la acción tiene una faz preventiva ante el riesgo de que se produzca el daño al derecho o al bien jurídico protegido (lo cual es esencial, por ejemplo, para el derecho ambiental, que busca centralmente la prevención del daño a los elementos ambientales, por la dificultad o imposibilidad de su restauración ó recomposición). Y tiene por otra parte, una faz de recomposición, restauración del derecho al estado anterior al daño, y/o rectificación de la acción u omisión que genera el daño. Asimismo, la acción puede comprender la reparación de los daños y perjuicios ocasionados, determinando en su caso la responsabilidad penal ${ }^{101}$ de la autoridad o persona responsable.

A los derechos colectivos enunciados de modo expreso en el artículo 135 de la Constitución Política del Estado (v.g. derecho al ambiente, derecho al patrimonio público, etc.), cabe adicionar ${ }^{102}$, entre otros, el catálogo de derechos colectivos de los pueblos indígenas reconocidos por la Constitución en el Título II, Capítulo IV (y desde ya, los derechos reconocidos por los instrumentos internacionales en la materia, que forman parte del bloque de constitucionalidad). En consecuencia, la acción popular es idónea para la exigencia de los derechos de los pueblos indígenas como: la consulta

\footnotetext{
${ }^{100}$ Cfr. Artículo 135 de la Constitución Política del Estado.

${ }^{101}$ Cfr. RIVERA, J. A., Justicia Constitucional, p. 490.

${ }^{102}$ Dado que la propia Constitución abre el alcance de la acción popular a otros derechos de similar naturaleza (derechos colectivos) reconocidos por el texto constitucional.
} 
previa y el consentimiento, el ejercicio de sus sistemas políticos, jurídicos y económicos acorde a su cosmovisión, a la territorialidad y a la titulación colectiva de tierras y territorios, al ambiente sano, etc.

La acción popular es una vía jurisdiccional principal y directa, con lo cual no exige para su interposición el haber agotado vías administrativas o judiciales ${ }^{103}$, ello a diferencia de la Acción de Amparo Constitucional y de la Acción de Cumplimiento que sí tienen dicha exigencia por ser acciones subsidiarias. De modo congruente con la mencionada característica, se debe subrayar también que se trata de una vía jurisdiccional inmediata y efectiva, que asume un proceso constitucional de tramitación sumarísima y extraordinaria $^{104}$ acorde con la tutela oportuna y plena de los derechos colectivos amenazados o vulnerados. Finalmente, cabe señalar que la acción popular no prescribe por el paso del tiempo, mientras subsista la vulneración o la amenaza a los derechos e intereses colectivos $^{105}$.

\section{B. Legitimación activa y efectos de la resolución}

La legitimación activa para interponer la acción popular es amplísima, siendo esta una de las características definitorias de la acción popular. En virtud a dicha legitimación, toda persona sin necesidad de demostrar un interés específico, particular o concreto sobre el bien a ser tutelado, está facultada a interponer la acción, y ello es así, porque los derechos e intereses colectivos, llamados también intereses de pertenencia difusa, no son exclusivos ni divisibles con relación a un sujeto determinado, pertenecen a toda la colectividad, y en esta virtud, todos/as los/as integrantes de ella están facultados (tienen un derecho-deber) a proteger el interés colectivo.

La Resolución del Tribunal o Juzgado de Garantías constitucionales, resultante de la acción popular, puede conceder o denegar la tutela solicitada. Por su parte, las determinaciones contempladas en la Resolución deben ser cumplidas de modo inmediato por los servidores públicos o por las personas individuales o colectivas pertinentes. Ello, sin perjuicio de la remisión de oficio de la Resolución al Tribunal Constitucional Plurinacional (TCP) para su revisión, el cual puede aprobar o revocar la

\footnotetext{
${ }^{103}$ Cfr. Artículo 136 de la Constitución Política del Estado.

${ }^{104}$ Cfr. RIVERA, J. A., op. cit., p. 488.

${ }^{105}$ Cfr. Artículo 136 de la Constitución Política del Estado.
} 
Resolución del Tribunal o Juzgado de garantías. La sentencia constitucional del TCP es vinculante e inapelable (causa estado).

C. Primeras experiencias de la aplicación de la acción popular en el país

Desde 2009 se han interpuesto las primeras acciones populares en el país, que han sido conocidas por Tribunales o Juzgados de Garantías Constitucionales de diferentes Departamentos, y sus Resoluciones se han remitido en revisión al TC. El órgano de control constitucional ha tenido retrasos de hasta 32 meses $^{106}$ para aprobar o revocar las Resoluciones remitidas a su conocimiento; ello, debido a la crisis que afectó al TC entre 2007 y 2009.

Cabe subrayar que si bien no se ha cumplido en los casos revisados el plazo de 48 horas entre la interposición de la Acción y el desarrollo de la audiencia pública y pronunciamiento de la Resolución por parte del Tribunal o Juzgado de Garantías ${ }^{107}$, dicha audiencia y Resolución se han realizado en plazos relativamente cortos, entre 6 y 24 días, lo que resulta ser mucho más breve que los largos tiempos que toman los procesos en la Jurisdicción ordinaria. Cabe, desde ya, enfatizar la necesidad de acortar estos plazos de modo que la acción popular sea realmente oportuna y efectiva a los fines de la tutela de los derechos colectivos.

Se han planteado acciones populares relacionadas con la tutela de derechos indígenas, derechos ambientales, la conservación de áreas verdes urbanas, y también, en el ámbito de la seguridad ciudadana. Si bien existen algunas acciones populares bien fundamentadas, se extraña en muchas otras una mayor consistencia jurídica y técnica para plantear acciones relacionadas con la tutela de derechos colectivos. En los siguientes meses y años la sociedad civil, abogados litigantes, y otros operadores de la Justicia Constitucional, tienen un reto mayor para capacitarse en la interposición de acciones para la tutela de derechos colectivos.

A continuación, se describen de modo breve algunos elementos relevantes en sentencias constitucionales vinculadas a la interposición de acciones populares.

\footnotetext{
${ }^{106}$ Cfr. SC 1984/2011-R.

${ }^{107}$ Conforme disponen los artículos 61 y 62 de la Ley N 27 del Tribunal Constitucional Plurinacional.
} 
- En la SC 1971/2011-R, de 7 de diciembre de 2011, el TC reconoce de modo expreso que los derechos de los pueblos indígenas originario campesinos (como el derecho a la territorialidad) tienen la naturaleza de derechos colectivos. ${ }^{108}$ En consecuencia, de acuerdo a la Constitución, la vía que corresponde para la tutela de estos derechos es la acción popular. No obstante ello, en la misma sentencia, el TC considera como no tutelable a través de la acción popular, la vulneración del derecho al reconocimiento de la personalidad jurídica de una comunidad campesina. Ello, a pesar de que dicho reconocimiento tiene una relación directa con el catálogo de derechos de los pueblos indígenas originarios contemplados por el artículo 30 de la Constitución (entre otros, con el derecho a que las instituciones de los pueblos indígenas sean parte de la estructura general del Estado).

- En la SC 1984/2011-R de 7/12/2011, el TC subraya las dificultades del demandante para aportar pruebas idóneas que le permitan patentizar la afectación de su derecho al ambiente sano (se pretendía demostrar un caso de contaminación acústica con fotografías). En este sentido, el $\mathrm{TC}$ ha señalado de modo razonable que: "el actor no puede prescindir de presentar la prueba minima que acredite los hechos denunciados, en razón a que la jurisdicción constitucional al sustanciar y resolver las acciones de defensa sometidas a su conocimiento, requiere de certidumbre sobre la lesión del o los derechos invocados para tutelarlos y protegerlos". Una prueba clara y bien estructurada es una condición necesaria para conseguir la tutela solicitada a la justicia constitucional, y mucho más cuando se trata de un proceso constitucional sumarísimo como el de la acción popular. ${ }^{109}$

- Cabe destacar también la SC 1982/2011-R que concede la tutela a favor de la Sociedad Protectora de Animales de Tarija y de otro ciudadano, para la protección de fauna silvestre en cautiverio, la misma que estaba siendo vejada en un zoológico sin condiciones adecuadas en la ciudad de Tarija. Asimismo, la sentencia establece

${ }^{108}$ Cfr. SC 1971/2011-R, 7 de diciembre de 2011, acápite III.2. Ámbito de protección. En similar sentido, la SC 1982/2011-R, señala que: "los derechos colectivos o intereses difusos, son los comúnmente conocidos por la doctrina como derechos de tercera generación; en otros términos, aquellos derechos que no corresponden a los intereses puramente individuales y subjetivos (...) derechos de tercera generación, o derechos de los pueblos o de solidaridad, que pertenecen a toda la comunidad y cada uno de sus miembros, en consecuencia, supraindividuales, entre los que se encuentran: "los derechos de las naciones y pueblos indígena originario campesinos (art. 30 de la CPE), derechos de las usuarias y los usuarios y de las consumidoras y consumidores (art. 75 de la CPE), derechos de las personas con discapacidad (art. 70 de la CPE), derecho a la paz (art. 10.I de la CPE), etc.” (SC 0788/2011-R de 30 de mayo)".

109 Otra acción popular con limitaciones en la presentación de las pruebas pertinentes y en la fundamentación del derecho vulnerado es la relacionada con la SC 1018/2011-R. 
obligaciones de hacer a cargo del Alcalde de Tarija (traslado de los animales silvestres a espacios con condiciones adecuadas).

\subsection{La acción de cumplimiento}

A. Objeto y naturaleza

La acción de cumplimiento tiene la finalidad de garantizar el cumplimiento efectivo de la Constitución y de las Leyes, y el respeto a los derechos constitucionales de las personas, cuando los/as servidores públicos sean renuentes a cumplir con sus mandatos constitucionales o legales. En consecuencia, esta acción tiene por objeto que el servidor público cumpla con el deber legal que ha omitido.

Se trata de una acción constitucional subsidiaria, por cuanto, solo puede ser interpuesta siempre que no existan vías administrativas o judiciales para su eficaz protección. ${ }^{110}$

Asimismo, cabe señalar que la acción es improcedente cuando "los derechos omitidos puedan ser garantizados mediante acciones de Libertad, Amparo Constitucional, Protección de Privacidad y Popular"111 . En este sentido, consideramos que siendo que la vía jurisdiccional constitucional destinada a la tutela de los derechos colectivos, como los derechos de los pueblos indígenas, es la Acción Popular, se debe interponer ésta acción y no la acción de cumplimiento, cuando la renuencia a cumplir con un mandato legal por parte del funcionario público afecte a un derecho colectivo.

Por otra parte, la acción de cumplimiento sólo puede ser interpuesta si previamente y de modo documentado se ha reclamado a la autoridad respectiva el cumplimiento del deber omitido, siendo ésta renuente a cumplir con su mandato constitucional o legal. ${ }^{112}$

A diferencia de la acción popular, la acción de cumplimiento prescribe con el paso del tiempo, ello por cuanto debe interponerse en un plazo máximo de seis meses computable a partir de la comisión de la vulneración alegada o de notificada la última decisión administrativa o judicial. ${ }^{113}$

\footnotetext{
${ }^{110}$ Cfr. Artículo 88 de la Ley No 27 - Ley del Tribunal Constitucional Plurinacional.

${ }^{111}$ Cfr. Artículo 89, inciso 1 de la Ley No 27 - Ley del Tribunal Constitucional Plurinacional.

${ }^{112}$ Cfr. Artículo 89, inciso 5 de la Ley No 27 - Ley del Tribunal Constitucional Plurinacional.

${ }^{113}$ Cfr. Artículo 59, de la Ley No 27 - Ley del Tribunal Constitucional Plurinacional.
} 
B. Legitimación activa y efectos de la resolución

La legitimación activa corresponde a la persona individual o colectiva afectada; ahora bien, consideramos que, siendo que el bien jurídico tutelado por esta acción es la eficacia de la ley ${ }^{114}$, corresponde a todos los ciudadanos el derecho - deber al cumplimiento cabal de la legislación interna, y por tanto, correspondería a todos la legitimación para plantear la acción de cumplimiento para el resguardo de este derechodeber. $^{115}$

En relación a los efectos de la Resolución resultante de la acción de cumplimiento, la Constitución y la Ley del Tribunal Constitucional Plurinacional establecen que de encontrarse cierta y efectiva la demanda se ordenará al funcionario público respectivo el cumplimiento inmediato del deber omitido, y en su caso, se determinará la responsabilidad civil o penal del mismo.

Finalmente, ya en relación a la aplicación de la acción de cumplimiento en el país, cabe señalar que si bien ya existen casos de planteamiento de esta garantía jurisdiccional, no se ha identificado en la base de datos de jurisprudencia en línea del Tribunal Constitucional Plurinacional ${ }^{116}$ casos relevantes en temas de derechos de pueblos indígenas o de medio ambiente, por lo que no se realizará el análisis de los mismos en este trabajo.

\section{CONCLUSIONES}

1. La justicia constitucional (JC) tiene un rol esencial para tamizar las políticas públicas y normas legales aprobadas por los órganos ejecutivo y legislativo, a través del filtro de los derechos constitucionales y de los tratados de derechos humanos que forman parte del bloque de constitucionalidad. Ello, a fin de que el Estado no pierda de vista su derrotero del cumplimiento y garantía de los derechos humanos en el país. En este

\footnotetext{
${ }^{114}$ El Profesor peruano Cesar Landa, citado por José Antonio Rivera, señala que: "no basta que una norma legislativa o administrativa sea aprobada mediante los requisitos formalmente y que sea conforme a las disposiciones sustantivas establecidas en la Constitución y en la Ley, sino que la eficacia del cumplimiento de las mismas se convierte en un derecho constitucional de los ciudadanos".

${ }^{115}$ El artículo 108 de la Constitución, sobre los deberes de los bolivianos y bolivianas, establece en primer lugar: el conocer, cumplir y hacer cumplir la Constitución, y los derechos contemplados en la Constitución.

${ }^{116}$ Revisión de la página web del TCP realizada en mayo de 2012.
} 
mismo sentido, la JC tiene un papel trascendental para brindar tutela efectiva a los derechos colectivos, en especial, a los derechos de los pueblos indígenas. ${ }^{117}$

2. Las Resoluciones de la JC que sean congruentes con los derechos constitucionales de las personas, pueden contribuir a la gobernabilidad democrática del país mediante decisiones firmes que sean respetadas y asumidas por todos los actores involucrados, previniendo o resolviendo conflictos socio-ambientales específicos vinculados a los derechos de los pueblos indígenas.

3. La Jurisprudencia constitucional emitida de modo previo a la promulgación de la nueva Constitución mantendrá vigencia en tanto sea congruente con la Constitución de 2009. En consecuencia, sentencias constitucionales como la SC 0045/2006 que limita los alcances y efectos del derecho de consulta previa de los pueblos indígenas, quedan sin efectividad por contraponerse a lo establecido en la nueva Constitución y en los tratados de derechos humanos ratificados por el país que forman parte del bloque de constitucionalidad.

4. En caso de dudas o ambigüedad de los órganos del Estado sobre la interpretación y alcances de los derechos de los pueblos indígenas, y cuando las normas internacionales fueran más favorables a los pueblos indígenas que el derecho interno, prevalecen las normas internacionales de derechos humanos en su aplicación e interpretación en el ámbito nacional, por mandato de la propia Constitución.

5. Siendo que la acción popular tiene por objeto la tutela de los derechos colectivos, ésta se constituye en una vía jurisdiccional idónea para la protección de los derechos de los pueblos indígenas. Asimismo, al tratarse de una acción directa, principal, inmediata y de proceso sumarísimo, puede permitir una tutela rápida, oportuna y efectiva de los derechos de los pueblos indígenas.

6. Dado que la acción de cumplimiento tiene una naturaleza subsidiaria en relación a otras acciones de tutela constitucional, cuando la renuencia del funcionario público a cumplir con un mandato legal afecta a un derecho colectivo, procede la acción popular como vía de tutela constitucional, y no así la acción de cumplimiento.

7. El uso adecuado y estratégico de la acción popular por parte de los pueblos indígenas del país para la prevención o reparación de daños socio-ambientales, y el otorgamiento

117 Ver de modo complementario otras conclusiones relacionadas con el primer período de funcionamiento de la JC en el acápite IV.4. de esta investigación. 
garantista de tutela por parte de la justicia constitucional, pueden contribuir a generar, controlar, rectificar y fortalecer políticas públicas relacionadas con los derechos de los pueblos indígenas. Ello, por cuanto, los efectos de la Resolución resultante de la acción popular benefician a todos/as los integrantes de la colectividad.

8. Las primeras acciones populares interpuestas en el país constituyen un buen indicador de la vitalidad del ejercicio de los derechos colectivos en el país, y permiten ser expectantes de un rol más gravitante de la JC en la tutela de los derechos de los pueblos indígenas. No obstante ello, existen muchos elementos a mejorar en relación a estas incipientes acciones populares. Por ejemplo, varias de ellas adolecen de debilidades técnicas en su fundamentación y planteamiento, y algunas Resoluciones de la JC acusan criterios todavía restrictivos en cuanto a la comprensión de los derechos de los pueblos indígenas. Tales aspectos deben ser revisados y subsanados por los actores de la JC en el futuro.

\section{RECOMENDACIONES}

1. Es imprescindible que los/as Magistrados/as del Tribunal Constitucional Plurinacional (TCP), y los/as Jueces de Tribunales o Juzgados de Garantías Constitucionales cuenten con un profundo conocimiento y sensibilidad sobre la cultura y derechos de los pueblos indígenas. Ello les permitirá realizar una valoración y lectura adecuadas de los casos, conflictos o vulneraciones de derechos que sean sometidos a su conocimiento, desde una posición garantista de los derechos de los pueblos indígenas.

2. El TCP debería mantener una Jurisprudencia Constitucional homogénea que de claridad y certidumbre sobre los contenidos y alcances de los derechos y garantías jurisdiccionales de los pueblos indígenas, de modo congruente con los mandatos de la Constitución y de los tratados internacionales de derechos humanos ratificados por el país.

3. Es necesario que tanto el TCP como los Tribunales y Juzgados de Garantías Constitucionales asuman un alto nivel de rendición de cuentas ante la sociedad civil sobre la razonabilidad y congruencia de sus Resoluciones a la luz de la Constitución y de los Tratados de derechos humanos. Estos estándares adecuados de rendición de cuentas serán la mejor garantía para la independencia de la Justicia Constitucional de 
los otros órganos estatales, así como, para su sostenibilidad institucional y la profundización de su legitimidad.

La necesidad de transparencia y rendición de cuentas en la JC se redobla después del cuestionado proceso de selección y elección de Magistrados/as del TCP, que para muchos ciudadanos ha puesto en duda la independencia del TCP en relación al Órgano ejecutivo.

4. El TCP y los Tribunales - Juzgados de Garantías Constitucionales deberían desarrollar un amplio y regular programa de educación constitucional orientado a la sociedad civil, que contribuya al conocimiento y cumplimiento de las normas constitucionales, así como, al conocimiento de los fines, objetivos y competencias de la JC. Estos programas deberían comprender a las organizaciones indígenas del país como destinatarios prioritarios.

5. Las organizaciones indígenas tienen un desafío importante para capacitarse sobre los contenidos y alcances de los derechos y acciones constitucionales. Capacitación que debería permear a organizaciones nacionales, regionales y locales. Por otra parte, sería conveniente que las organizaciones indígenas consideren las oportunidades y desafíos del planteamiento de acciones populares para la tutela de sus derechos colectivos, y como parte de sus repertorios de acciones de incidencia.

6. Las organizaciones de la sociedad civil, defensores de derechos humanos, abogados de interés público, y otros actores relacionados con la promoción y defensa de los derechos de los pueblos indígenas, deben capacitarse sobre las nuevas acciones de tutela constitucional, sobre los derechos colectivos, y los desafíos que estos representan en términos de fundamentación de demandas ante la JC, presentación de pruebas, gestión de los efectos de la sentencia, etc.

7. Las organizaciones de la sociedad civil (OSC) también deberían participar facilitando los procesos de capacitación de las organizaciones indígenas, y en caso de que éstas lo consideren favorable, acompañar los procesos de planteamiento de acciones populares para la tutela preventiva o reparadora de sus derechos colectivos. Por otra parte, las OSC deberían jugar un rol central en la exigencia de transparencia y rendición de cuentas de la Justicia Constitucional.

8. Los centros académicos, universidades, asociaciones de profesionales, etc., también están llamados a jugar un rol importante en la difusión y sensibilización sobre la 
importancia, contenidos y alcances de los derechos y garantías constitucionales de los pueblos indígenas, entre los estudiantes, profesores, y la sociedad civil en su conjunto.

9. Los órganos ejecutivo y legislativo deben respetar la independencia de la Justicia Constitucional y cumplir cabalmente con los mandatos de sus Resoluciones, a fin de fortalecer el Estado de derecho, el equilibrio de poderes y la gobernabilidad democrática en el país.

10. Los medios de comunicación también deberían contribuir en la difusión y sensibilización sobre la importancia, contenidos y alcances de los derechos colectivos de los pueblos indígenas, la jurisprudencia constitucional relacionada con tales derechos, y los avances/limitaciones de rendición de cuentas y transparencia de la Justicia Constitucional, entre otros aspectos.

\section{BIBLIOGRAFÍA}

BALDIVIESO JINÉS, M., La Sentencia Constitucional 2003/2010-R - Itika Guasu y sus consecuencias para el Derecho a la Consulta en Bolivia. Ponencia realizada en el Taller para periodistas "La Consulta Previa, Libre e informada para Pueblos Indígenas", organizado por CEADESC en 9 de marzo 2012.

BALZA ALARCÓN, R., Tierra, Territorio y Territorialidad Indígena, Publicación de APCOB, IWGIA, SNV, Santa Cruz de la Sierra, 2001.

BIDART CAMPOS, G., Tratado elemental del derecho constitucional argentino, Ed. Ediar, Nueva edición ampliada y actualizada a 1999-2000, Tomo I-A, Buenos Aires, 2000 .

CENTRO DE ESTUDIOS PARA EL DESARROLLO LABORAL Y AGRARIO (CEDLA), Las prefecturas no usan la renta de los hidrocarburos para el desarrollo. Ingresos millonarios, gastos improductivos y poca transparencia, La Paz, 2010.

CHAPLIN, A., "Movimientos sociales en Bolivia. De la fuerza al poder", en Community Development Journal, Oxford University Press, 2010.

CHIVI VARGAS, I., “Justicia indígena y jurisdicción constitucional: Bolivia, 20032005", en Derechos Humanos y Acción Defensorial. Revista Especializada del Defensor del Pueblo en Bolivia, núm. 1, 2006. 
CRABTREe, J., Perfiles de la protesta. Política y movimientos sociales en Bolivia, Publicación de Fundación UNIR y Fundación PIEB, La Paz, 2005.

DEFENSORÍA DEL PUEBLO, Informe Defensorial respecto a la violación de los derechos humanos en la Marcha Indígena, La Paz, noviembre de 2011. , XV Informe a la Asamblea Legislativa Plurinacional 2012, La Paz, 2013.

DERMISAKY, P., Justicia constitucional y Estado de derecho, Ed. Alexander, 2a ed., La Paz, 2005.

FUNDACIÓN UNIR, Informe sobre conflictividad en Bolivia (Junio a diciembre de 2010), La Paz, febrero de 2011. , Las piezas del conflicto, Ed. Plural, La Paz, 2005.

GARCÍA LINERA, A. et al., Sociología de los movimientos sociales en Bolivia. Estructuras de movilización, repertorios culturales y acción política, Publicación de Plural editores, AGRUCO y NCCR Norte Sur, 4a . ed., La Paz; 2010.

GINE, J. y VILlARROEL, F., Total E\&P Bolivia y sus impactos en los derechos humanos del pueblo guaraní de la capitanía de Muyupampa, Publicación del Centro de Estudios Aplicados a los Derechos Económicos, Sociales y Culturales (CEADESC), Santa Cruz, 2011.

GRUENBERGER, J. y ZAMBRANA, G.; "Política ambiental", en Informe del estado ambiental de Bolivia 2010, Publicación de la Liga de Defensa del Medio Ambiente (LIDEMA), La Paz, 2010.

GUZMÁN, I., Octava marcha indígena en Bolivia: Por la defensa del territorio, la vida y los derechos de los pueblos indígenas, Publicación del Centro de Investigación y Promoción del Campesinado (CIPCA), La Paz, 2012.

IBARGÜEN, G., "Restricciones de Acceso a la Justicia Constitucional", en Derechos Humanos y Acción Defensorial. Revista Especializada del Defensor del Pueblo en Bolivia, núm. 1, 2006.

IWGIA (Kathrin Wessendorf, compilación y edición), El mundo indígena 2011, Ed. IWGIA, Copenhague, 2011. 
ORGANIZACIÓN DE LAS NACIONES UNIDAS, Informe del Relator Especial sobre la situación de los derechos humanos y las libertades fundamentales de los indígenas, Sr. Rodolfo Stavenhagen. Misión a Bolivia, 18/02/2009. , Informe de la Alta Comisionada de las Naciones Unidas para los Derechos Humanos sobre las actividades de su oficina en el Estado Plurinacional de Bolivia. Consejo de Derechos Humanos. $19^{\circ}$ Período de Sesiones, 2/02/2012.

OXFAM en BOLIVIA (Programa de Industrias Extractivas), Repsol YPF en el Chaco boliviano: El pueblo guaraní en el proceso de defensa de sus derechos, 2007.

PAYE, L. et al.; Compendio de espaciomapas de TCO en tierras bajas. Tenencia y aprovechamiento de recursos naturales en territorios indígenas, Publicación de CEDLA, La Paz, 2011.

PÉREZ CASTELLÓN, A., "Política energética y "vivir bien": algunas herramientas conceptuales y de gestión para tender cables a tierra”, en Revista de Debate Social y Jurídico Artículo Primero, Año 14, Número 21, Publicación de CEJIS, Santa Cruz, 2011.

RIBERA ARISMENDI, M, Crónica ambiental 2007-2011. Retrospectiva y actualización de problemáticas priorizadas, Publicación de la Liga de Defensa del Medio Ambiente (LIDEMA), La Paz, 2011.

RIVERA SANTIVAÑEZ, J., Jurisdicción constitucional. Procesos constitucionales en Bolivia, Ed. Kipus, $3^{\text {a }}$ ed., Cochabamba, 2011.

RODRÍGUEZ VELTZÉ, E., “Órgano judicial y Tribunal Constitucional Plurinacional”, en Miradas. Nuevo texto constitucional, Publicación de Idea Internacional, Universidad Mayor de San Andrés y Vicepresidencia del Estado Plurinacional, La Paz, 2010.

VARGAS, M., “Demanda de Consulta previa en territorio Jach'a Suyu Pakajaqi”, en Revista de Debate Social y Jurídico Artículo Primero, Año 14, Número 21, Publicación de CEJIS, Santa Cruz, 2011.

ZUAZO, M., “¿Los movimientos sociales en el poder? El gobierno del MAS en Bolivia”, en Revista Nueva Sociedad, Número 227, mayo-junio 2010, Caracas.

\section{ENTREVISTAS}

KOMADINA, J, Sociólogo, en mayo de 2012. 
PUMA ZÁRATE, B., Técnica de apoyo en temas legales de la Asamblea del Pueblo Guaraní, en mayo de 2012.

RIVERA SANTIVAÑEZ, J., ex Magistrado del Tribunal Constitucional, en mayo de 2012. 